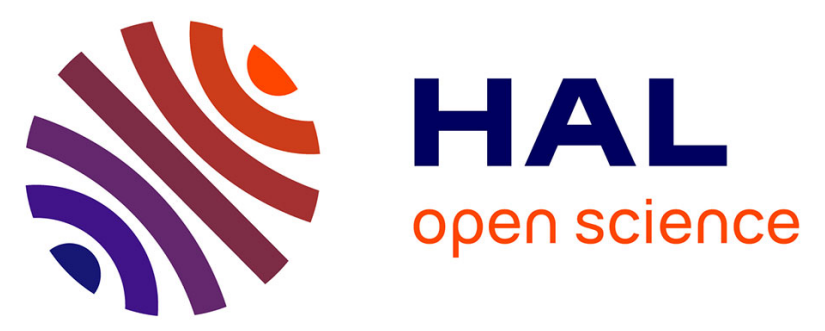

\title{
Balancing Microalgae and Nitrifiers for Wastewater Treatment: Can Inorganic Carbon Limitation Cause an Environmental Threat?
}

Francesca Casagli, Simone Rossi, Jean-Philippe Steyer, Olivier Bernard, Elena Ficara

\section{To cite this version:}

Francesca Casagli, Simone Rossi, Jean-Philippe Steyer, Olivier Bernard, Elena Ficara. Balancing Microalgae and Nitrifiers for Wastewater Treatment: Can Inorganic Carbon Limitation Cause an Environmental Threat?. Environmental Science and Technology, 2021, 55 (6), pp.3940-3955. 10.1021/acs.est.0c05264 . hal-03219531

\section{HAL Id: hal-03219531 \\ https://hal.inrae.fr/hal-03219531}

Submitted on 6 May 2021

HAL is a multi-disciplinary open access archive for the deposit and dissemination of scientific research documents, whether they are published or not. The documents may come from teaching and research institutions in France or abroad, or from public or private research centers.
L'archive ouverte pluridisciplinaire HAL, est destinée au dépôt et à la diffusion de documents scientifiques de niveau recherche, publiés ou non, émanant des établissements d'enseignement et de recherche français ou étrangers, des laboratoires publics ou privés.

\section{(c)(1)}

Distributed under a Creative Commons Attribution| 4.0 International License 


\title{
Balancing Microalgae and Nitrifiers for Wastewater Treatment: Can Inorganic Carbon Limitation Cause an Environmental Threat?
}

\author{
Francesca Casagli, Simone Rossi, Jean Philippe Steyer, Olivier Bernard, and Elena Ficara*
}

Cite This: Environ. Sci. Technol. 2021, 55, 3940-3955

Read Online

ABSTRACT: The first objective of this study is to assess the predictive capability of the ALBA (ALgae-BActeria) model for a pilot-scale $\left(3.8 \mathrm{~m}^{2}\right)$ highrate algae-bacteria pond treating agricultural digestate. The model, previously calibrated and validated on a one-year data set from a demonstrative-scale raceway $\left(56 \mathrm{~m}^{2}\right)$, successfully predicted data from a six-month monitoring campaign with a different wastewater (urban wastewater) under different climatic conditions. Without changing any parameter value from the previous calibration, the model accurately predicted both online monitored variables (dissolved oxygen, $\mathrm{pH}$, temperature) and off-line measurements (nitrogen compounds, algal biomass, total and volatile suspended solids, chemical oxygen demand). Supported by the universal character of the model, different scenarios under variable weather conditions were tested, to investigate the effect of key operating parameters (hydraulic retention time, $\mathrm{pH}$ regulation, $\mathrm{k}_{\mathrm{L}} \mathrm{a}$ ) on algae

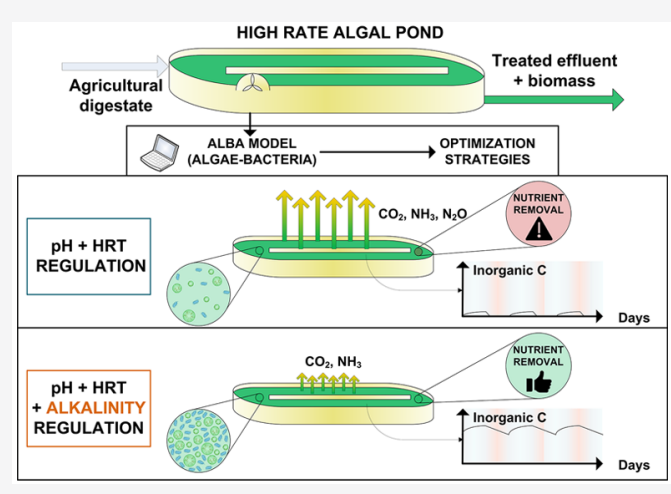
biomass productivity and nutrient removal efficiency. Surprisingly, despite $\mathrm{pH}$ regulation, a strong limitation for inorganic carbon was found to hinder the process efficiency and to generate conditions that are favorable for $\mathrm{N}_{2} \mathrm{O}$ emission. The standard operating parameters have a limited effect on this limitation, and alkalinity turns out to be the main driver of inorganic carbon availability. This investigation offers new insights in algae-bacteria processes and paves the way for the identification of optimal operational strategies. KEYWORDS: Microalgae-bacteria process modeling, wastewater remediation, long-term validation, alkalinity, greenhouse gas emissions

\section{INTRODUCTION}

High Rate Alga-Bacterial Pond (HRABP) is a promising technology for wastewater treatment. ${ }^{1,2}$ The process overcomes some critical aspects of conventional biological processes by reducing the oxygen demand and opening new routes for nitrogen and phosphorus recovery. Indeed, the photosynthetic activity of microalgae can provide the necessary oxygen to support bacterial needs and therefore avoid the energy consumption associated with external aeration. ${ }^{3-6}$

In addition, combining removal of nitrogen and phosphorus by algae and nitrifying bacteria can enhance the nitrogen conversion capacity of the system. By providing oxygen to nitrifiers, ${ }^{7}$ algae substantially increase the overall ammonium removal capacity of the system, ${ }^{8}$ while nitrifiers reduce the oxygen level below the inhibition thresholds for algae. Nitrification, in turn, helps by keeping the ammonium concentration low, thus reducing the risk of free ammonia inhibition on algae, especially when high strength wastewaters are to be treated. ${ }^{10,11}$ Nitrifiers convert ammonium into nitrate that can be uptaken by the algae. The combination between algae and nitrifying bacteria has also some drawbacks, inducing negative interactions like the competition for $\mathrm{CO}_{2}$ or micronutrients ${ }^{12}$ or the inhibition of bacterial growth when the photosynthesis increases the $\mathrm{pH}$ level. ${ }^{13}$ These complex interplays make the overall dynamics of nitrifiers/algae especially challenging to understand and predict, as well as highly dependent on the composition of the wastewater to be treated and on the operation parameters. ${ }^{14}$ The HRABP efficiency is also seasonal-dependent, and low temperature and solar radiation conditions can seriously affect the overall microalgae growth and its synergy with bacteria, ${ }^{15}$ potentially leading to the collapse of the system. ${ }^{16}$ Moreover, the overall dynamics of the algae/bacteria community can affect atmospheric emissions, not only in terms of free ammonia stripping but also by modulating the conditions promoting $\mathrm{N}_{2} \mathrm{O}$ emission. ${ }^{17-19}$

These inherent complexities explain why contrasting conclusions have been drawn on the synergy and competition between algae and bacteria.

Mathematical models are powerful tools for understanding, predicting, and optimizing bioprocesses, especially for unraveling the complex nonlinear interactions among microorganisms. As for anaerobic digestion and activated sludge

Received: August 5, 2020

Revised: February 17, 2021

Accepted: February 17, 2021

Published: March 3, 2021 
processes, reference validated models $\mathrm{ADM1}^{20}$ and $\mathrm{ASMs}^{21}$ turned out to be efficient tools currently used for supervision and process operation. To date, more than 300 models are available focusing on microalgae metabolism. ${ }^{22}$ However, only a minority of them were developed for modeling mixed algalbacterial cultures in raceway ponds. Most of them were not calibrated and/or validated on a long-term data set (i.e., beyond 1 week of experimental data in outdoor conditions). In addition, only nine models for wastewater remediation adopted the IWA standard nomenclature with an explicit stoichiometric matrix, thus facilitating their integration with plant-wide modeling platforms.

The ALBA model ${ }^{23}$ integrates all the physical (temperature, evaporation, gas-liquid exchange, hydraulics), chemical (acid/ base equilibria and $\mathrm{pH}$ ), and biological (algal and bacterial growth and decay) submodels required to efficiently predict the system behavior. The ALBA model was first presented in Casagli et al. ${ }^{23}$ The model was built up to simulate algalbacterial synergistic interactions and competitions, to evaluate the HRABP remediation performances, and to explore the feasibility of integrating it in existing WasteWater Treatment Plants (WWTPs) to convert them into Water Resource Recovery Facilities (WRRFs).

The biological dynamics of the ALBA model is driven by the functions representing the influence of environmental factors (light, temperature, $\mathrm{pH}$, oxygen) and of nutrient availability through the Liebig's minimum law. The ALBA model can be compared with existing reference models for bacteria (ASMs) and for algae-bacteria consortia, ${ }^{24-29}$ as reported in Table 1 . For most of the models, the dependence of biomass growth on nutrient availability is modeled by the typical Monod-like kinetics. Only the modified ASM3 includes a version implementing phototrophic growth on nitrogen storage compounds. Other published models on algae metabolism adopt the Droop model, such as the ASM A, ${ }^{30}$ though they do not include interactions with bacteria and are therefore not reported in Table 1 . Among the models in Table 1 , only the modified RWQM1, the BIO_ALGAE2 and the ALBA models account for multiple nutrient limitations (nitrogen, phosphorus, and inorganic carbon).

To be accurate, models of outdoor processes must be proven successful in predicting the behavior over all four seasons and daily dynamics, induced by the solar and meteorological cycles for the fast-changing variables, such as dissolved oxygen (DO) and $\mathrm{pH}$. The ALBA model was validated over a period of 413 days covering all the seasons both for daily and seasonal dynamics. Furthermore, none of these models are fully predictive because the temperature of the pond needs to be measured.

In this paper, the ALBA model-previously validated on a synthetic urban wastewater ${ }^{23}$-was tested on a pilot-scale HRABP processing an agricultural digestate and located in a piggery farm in Northern Italy. The first objective was to challenge the ALBA model and its current calibration on a long time scale, including the start-up phase, with a different type of influent and different environmental conditions (Csb instead of Csa climatic area, according to the climatic classification proposed by Peel et al. ${ }^{31}$ ). Moreover, a simple but accurate sub-model was included to allow the ALBA model to forecast the in-pond temperature from air temperature data, making it a locally predictive tool to assess seasons or climate effects on a yearly time frame.
The second objective of this work is to optimize algal productivity and nutrient removal rates, while considering environmental impacts including atmospheric emissions. Specifically, the effect of key operation parameters such as hydraulic retention time (HRT), $\mathrm{pH}$ control set-point, and volumetric liquid/gas mass transfer coefficient $\left(\mathrm{k}_{\mathrm{L}} \mathrm{a}\right)$ were considered. Simulations revealed the competition for inorganic carbon between nitrifiers and microalgae which not only degrades the system performance but also triggers conditions favorable for $\mathrm{N}_{2} \mathrm{O}$ production.

\section{MATERIALS AND METHODS}

2.1. Case Study and Experimental Data Set. A detailed description of the experimental setup, field data collection, level of experimental replication, and treatment performances can be found in Pizzera et al. ${ }^{32}$ The HRABP, with a surface of $3.8 \mathrm{~m}^{2}$ and an operational volume of $0.88 \mathrm{~m}^{3}$, was installed on a large-scale piggery farm located in Northern Italy. In this farm, the excess sludge produced by the local WWTP was codigested with other agricultural wastes (chopped corn and barley, poultry manure, and olive pomace) in a biogas plant. The liquid fraction of the digested sludge (centrate) was separated by centrifugation and fed to the HRABP, after dilution with tap water to reduce nutrient concentrations. The HRABP was operated continuously for 189 days (31/05/ 2016-06/12/2016). Different dilution factors were applied to the centrate (i.e., a dilution factor of 5, until $17 / 09 / 2016$, and a dilution factor of 3 until the end of the experimentation). The inflow rate was set to achieve an average HRT of 10 days until 11/10/2016; then, the HRT was increased to 20 days to compensate for temperature reduction. The mixing was ensured by a paddle wheel, operated at $20 \mathrm{rpm}$. The volumetric mass transfer coefficient $\left(\mathrm{k}_{\mathrm{L}} \mathrm{a}\right)$ of the HRABP was experimentally determined during abiotic tests, resulting in a final value of $30.5 \mathrm{~d}^{-1}$ (as detailed in SI.12) which is very close to $34 \mathrm{~d}^{-1}$ estimated for the $56-\mathrm{m}^{2}$ pond on the basis of which the model was calibrated. ${ }^{23}$ The reactor was equipped with a contact cylinder for $\mathrm{CO}_{2}$ bubbling to reduce $\mathrm{pH}$ when it overpassed a threshold $\left(\mathrm{pH}_{\text {threshold }}=8\right.$ until 16/06/2016, then $\left.\mathrm{pH}_{\text {threshold }}=7.5\right)$. Influent characteristics were monitored once a week by measuring the organic matter content (total and soluble COD), inorganic nitrogen compounds (Total Ammoniacal Nitrogen, TAN and nitrate, $\mathrm{N}-\mathrm{NO}_{3}{ }^{-}$), Total Kjeldahl Nitrogen (TKN), phosphate $\left(\mathrm{P}-\mathrm{PO}_{4}{ }^{3-}\right)$, and Total Suspended Solids (TSS). The mixed liquor in the HRABP was monitored twice a week, and the analyses were performed by spectrophotometric test kits on the following: TAN, nitrite (N$\mathrm{NO}_{2}^{-}$), nitrate, phosphate, and COD (total and soluble fractions). Optical density at $680 \mathrm{~nm}$ (to provide an estimate of the chlorophyll- $a$ content), TSS, and volatile suspended solids (VSS) were measured once a week, together with algal cell counts. The reactor was also equipped with two online probes recording $\mathrm{pH}$, temperature, and $\mathrm{DO}$ concentration (refer to Pizzera et al. ${ }^{32}$ for more details).

Standard deviations for on-line probes and off-line measurements were computed through the variation coefficient (further detailed in SI.2.).

2.2. ALBA Model Overview. All details on the ALBA model can be found in Casagli et al. ${ }^{23}$ and are recalled in SI.11. The biological sub-model (17 variables, 19 processes) considers a mixed culture of algae, heterotrophic bacteria, and nitrifiers, the latter including Ammonium Oxidizing Bacteria (AOB) and Nitrite Oxidizing Bacteria (NOB). The 

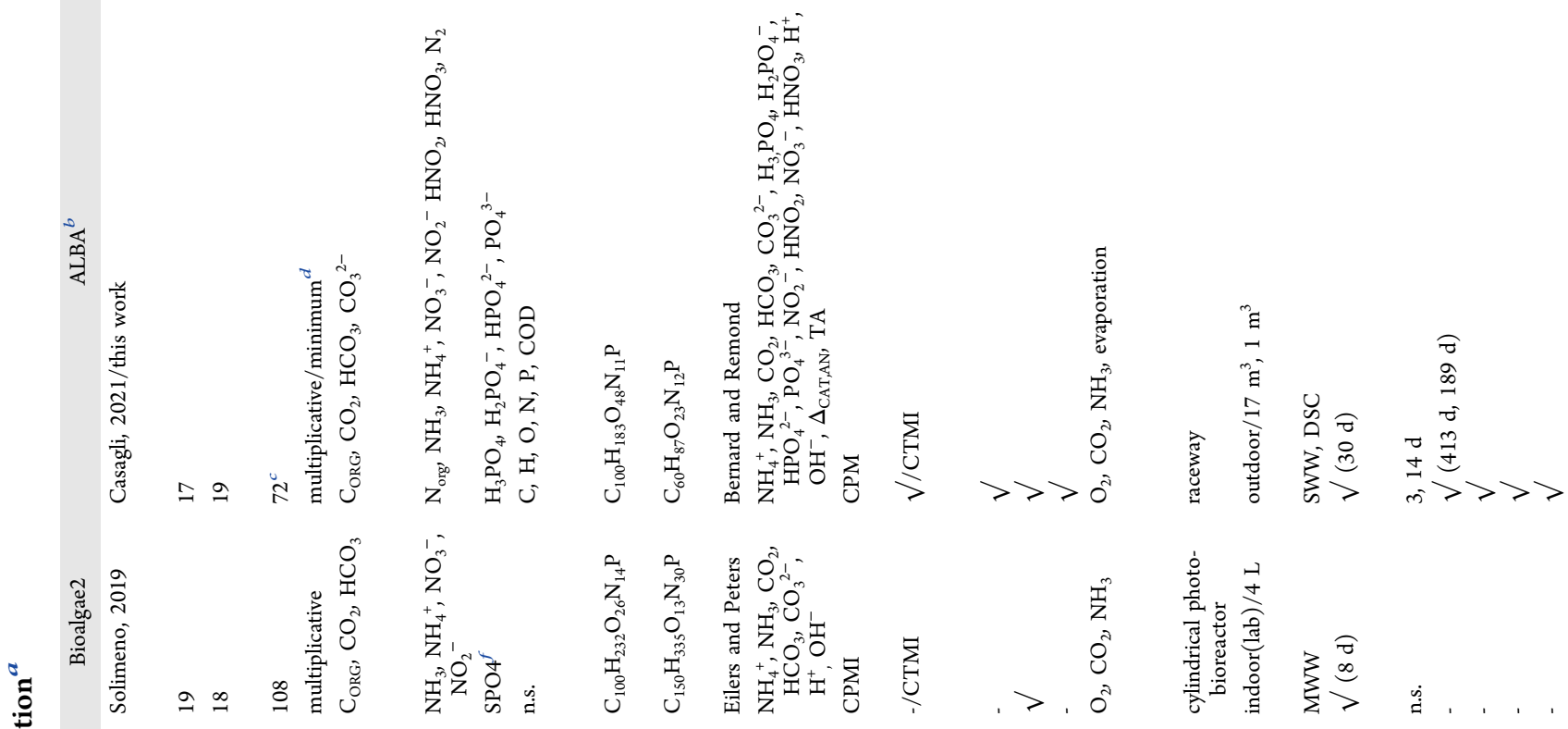

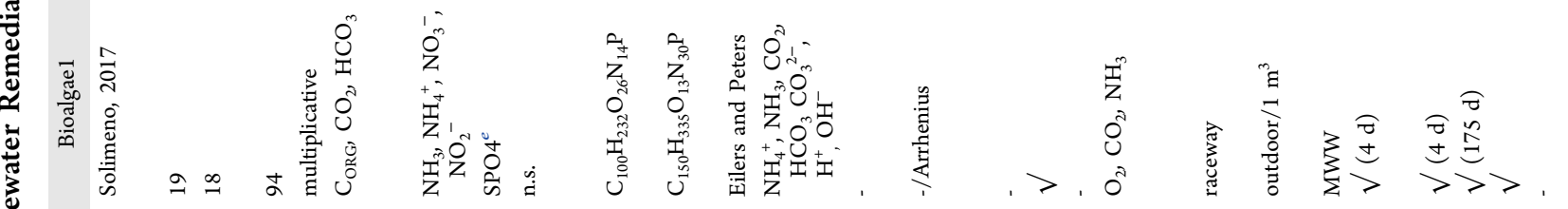

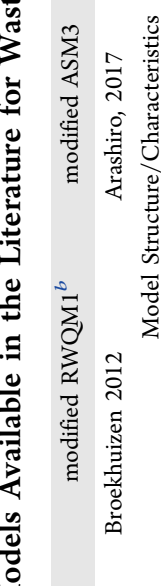

\section{8 a}


mass conversions are comprehensively described by the Petersen matrix, through which the conservation of COD, C, $\mathrm{N}, \mathrm{O}, \mathrm{P}$, and $\mathrm{H}$ is verified. The photosynthesis response to irradiance is described by a reparametrized Haldane function and accounts for light penetration through the Beer-Lambert equation. ${ }^{33} \mathrm{~A}$ minimum law is used to describe the growth limitation from multiple substrates (carbon, nitrogen, and phosphorus). The $\mathrm{pH}$ sub-model is based on dissociation equilibria and ionic species mass balances, according to the one proposed in the ADM1 model. ${ }^{20}$ The $\mathrm{CO}_{2}, \mathrm{NH}_{3}$, and $\mathrm{O}_{2}$ stripping/dissolution were included, quantifying their rates through the $\mathrm{k}_{\mathrm{L}}$ a. The influence of $\mathrm{pH}$ on algae and bacteria metabolism is implemented using the function proposed by Rosso et al., ${ }^{34}$ i.e., the Cardinal pH Model (CPM). The temperature dependence for growth and respiration rates is considered for all the biomasses and modeled by the Cardinal Temperature Model with Inflection (CTMI), ${ }^{35}$ while the Arrhenius function is chosen for modeling decay rates (see Table SI.11.6).

2.2.1. Pond Temperature Submodel and $\mathrm{pH}$ Regulation Scheme. In order to simulate the process behavior under any meteorological condition, a simple model was developed to predict the temperature in the raceway.

This model estimates the in-pond temperature from the available air temperature data, and it was calibrated on this case study. More specifically, the pond temperature was calculated according to the following regression (eq $1, R^{2}=0.98$ )

$$
T_{\mathrm{POND}}(t)=0.46 \cdot T_{\mathrm{AIR}}(t)+0.49 \cdot T_{\mathrm{AIR}}(t-4)+2.18
$$

where $T_{\mathrm{POND}}(t)\left[{ }^{\circ} \mathrm{C}\right]$ is the calculated pond temperature at time $t, T_{\mathrm{AIR}}(t)$ is the measured air temperature at time $t$, and $T_{\mathrm{AIR}}(t-4)$ is the air temperature measured $4 \mathrm{~h}$ before time $t$. The $4 \mathrm{~h}$ delay turned out to be optimal to best predict the pond temperature, see details in SI.7. Although more mechanistic models exist, ${ }^{36,37}$ they were not considered in this study. Unlike typical full-scale raceway ponds, the pilotscale raceway was not lying on the ground (no conductivity with the ground). Developing a thermal model for this reactor would have required dedicated developments though without upscaling perspectives.

On top of the ALBA model, a $\mathrm{pH}$ control system simulated the operation conditions applied in the pilot plant under study. The $\mathrm{pH}$ control scheme was based on the injection of a pure $\mathrm{CO}_{2}$ flow when the $\mathrm{pH}$ value exceeded the set-point. The $\mathrm{CO}_{2}$ flow rate was proportional to the difference between the $\mathrm{pH}$ value and the $\mathrm{pH}$ set-point (SI.8).

2.2.2. Numerical Integration. The software platform used for numerical simulations is AQUASIM, ${ }^{38}$ which has been used by many authors for modeling biological wastewater-treating systems. ${ }^{25,27,39}$ The raceway was simulated as a completely mixed reactor. Indeed, the mixing of the smaller raceways used in this study turned out to be close to ideal. However, largescale ponds can be imperfectly mixed, and a more complicated hydrodynamics model must then be used (e.g., Demory et al. $\left.{ }^{40}\right)$.

2.2.3. Model Validation and Evaluation Criteria. The ALBA model was previously calibrated and validated for 443 days from a demonstrative-scale raceway $\left(56 \mathrm{~m}^{2}\right)$ in France, treating synthetic municipal wastewater. ${ }^{23}$ More details regarding the calibration strategy can be found in our previous work. $^{23}$ Briefly, a sensitivity analysis was first conducted by running simulations under typical seasonal conditions and following a periodic regime for the most relevant environ- 

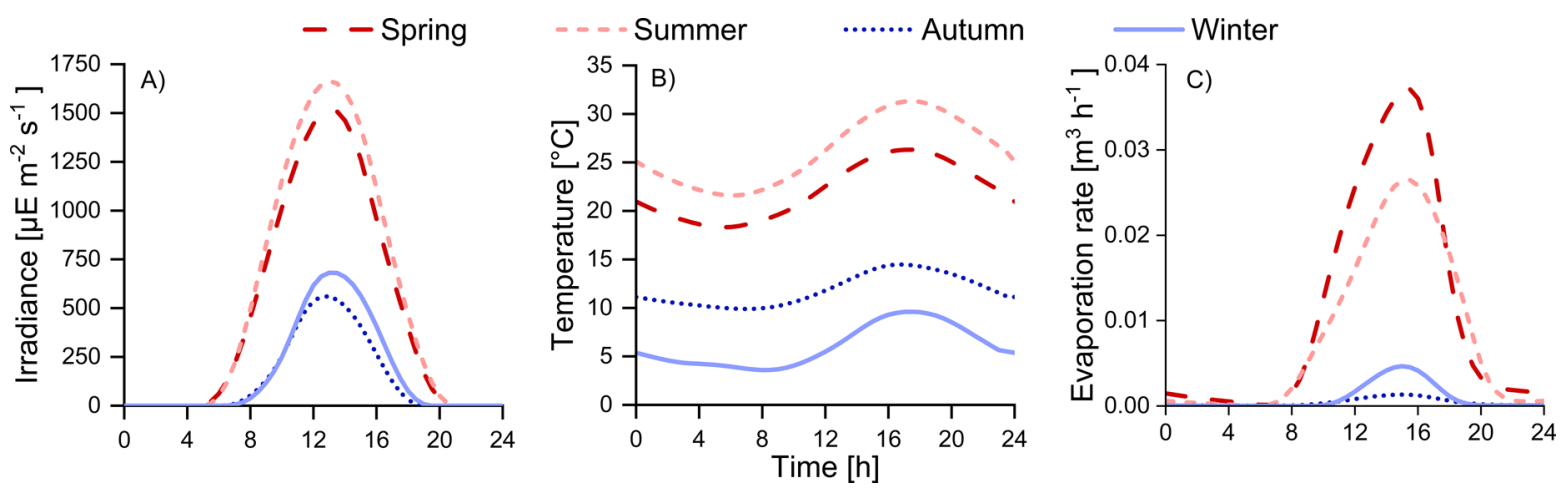

Figure 1. Average daily variation for each seasonal scenario: light (A), temperature (B), and evaporation rate (C).

Table 2. Summary of the Measurements Taken during the Monitoring Campaign: Influent Characteristics, Online Reactor Probes, and Environmental Conditions

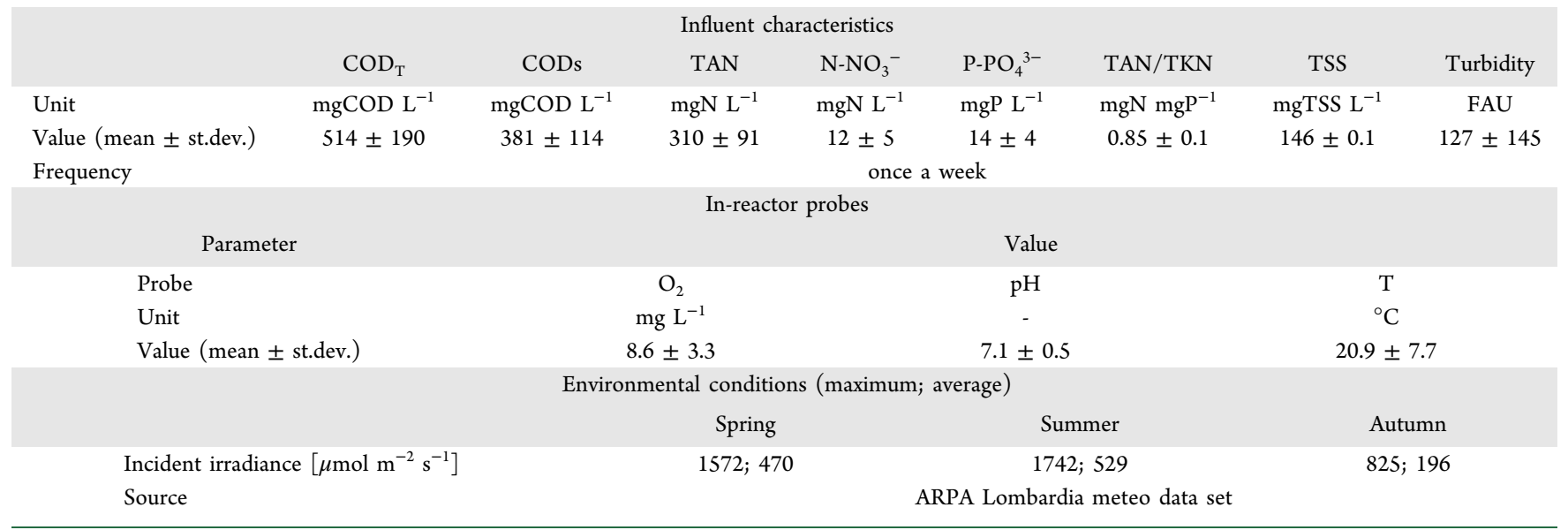

mental conditions (i.e., light, temperature, and evaporation rate). This allowed the identification of a subset of most sensitive parameters, that were subsequently ranked according to the value of the absolute-relative sensitivity functions. A similar sensitivity analysis was performed here and provided similar results.

These parameters were then calibrated in Casagli et al. ${ }^{23}$ and were not modified here, even though the two case studies differ from the process design, wastewater type, and climate.

The parameter error propagation was computed using the sensitivity functions (see SI.13), and 95\% confidence intervals on the modeled predictions were assessed.

Model performances were evaluated with the modified Theil's Inequality Coefficient (TIC, eq 2$)^{41}$

$$
\mathrm{TIC}=\frac{\sqrt{\sum_{i}\left(\operatorname{sat}_{\sigma}\left(y_{\mathrm{s}, i} y_{\mathrm{m}, i}\right)\right)^{2}}}{\sqrt{\sum_{i} y_{\mathrm{s}, i}{ }^{2}}+\sqrt{\sum_{i} y_{\mathrm{m}, i}{ }^{2}}}
$$

where $y_{\mathrm{s}, i}$ is the simulated value at the time-point $i ; y_{\mathrm{m}, i}$ is the measured value; and $\operatorname{sat}_{\sigma}\left(y_{\mathrm{s}, i} y_{\mathrm{m}, i}\right)$ is a function assuming a value of zero, when both $y_{\mathrm{m}, i}$ and $y_{\mathrm{s}, i}$ are lower than the standard deviation of the associated measurements (identifying an ideal fit) and assuming the value $\operatorname{sat}_{\sigma}\left(y_{\mathrm{s}, i} y_{\mathrm{m}, i}\right)=y_{\mathrm{s}, i}-y_{\mathrm{m}, i}$ otherwise.

The TIC value was computed for the whole set of experimentally observed variables (i.e., $\mathrm{pH}, \mathrm{DO}$, ammonium, nitrite and nitrate nitrogen, TSS, soluble COD, and algal biomass), either for the entire experimental campaign or season by season. The difference between simulated and observed values is normalized according to the amplitude of the variable, and the model is considered to have a good fit when the efficiency criterion approaches zero.

2.3. Meteorological Data and Climatic and Operational Scenarios. Meteorological data-including incident irradiance, air temperature, air humidity, wind speed, and rainfall-were provided by the Lombardy Environmental Protection Agency (ARPA Lombardia, www.arpalombardia. it). The evaporation rate was also investigated and computed on the basis of the available meteorological data (see SI.4), through the model provided by Béchet et ll. $^{36} \mathrm{~A}$ good prediction of the evaporation contribution is indeed fundamental because it significantly influences the hydraulic balance, hence the in-pond concentrations, further affecting light penetration and process rates. ${ }^{42}$

Four different climatic scenarios representative of each season were developed computing the most relevant environmental conditions (i.e., light, pond temperature, and evaporation rate), by averaging hourly weather data over each season. In this way, a typical daily pattern was defined and extended to run simulations under established periodic regime (see Figure 1). The same average influent wastewater characteristics were considered for all seasons (Table 2). Subsequently, several operational scenarios were tested by varying the HRT, $\mathrm{pH}$ set point, $\mathrm{k}_{\mathrm{L}} \mathrm{a}$, and total alkalinity (TA), as reported in Table 3 . Two extreme $\mathrm{k}_{\mathrm{L}}$ a values were selected, consistently with Casagli et al. ${ }^{23}$ The first value, $\mathrm{k}_{\mathrm{L}} \mathrm{a}=34 \mathrm{~d}^{-1}$, is typical of a condition of strong mixing in pilot-scale ponds, in which the algal-bacterial suspension is agitated through the paddle wheel and a high mass transfer rate is obtained. This 
Table 3. Parameters Set for the Selected Operational Scenarios

$\begin{array}{ccccc}\text { Parameter tested } & \text { Scenario no. } & \text { HRT }(\mathrm{d}) & \mathrm{pH} \text { set-point } & \mathrm{k}_{\mathrm{L}} \mathrm{a}\left(\mathrm{d}^{-1}\right) \\ \mathrm{k}_{\mathrm{L}} \mathrm{a} & \mathrm{S} 1 & 10 & 7.5 & 34 \\ & \mathrm{~S} 2 & & & 0.5 \\ \mathrm{HRT} & \mathrm{S} 3 & 2 & 7.5 & 34 \\ & \mathrm{~S} 4 & 5 & & \\ & \mathrm{~S} 5 & 15 & & \\ \mathrm{pH} & \mathrm{S} 6 & 20 & & 34 \\ & \mathrm{~S} 7 & 5 & 6.5 & \\ & \mathrm{~S} 8 & & 7 & \\ & \mathrm{~S} 9 & & 8 & 34 \\ \mathrm{TA}^{b} & \mathrm{~S} 10 & \mathrm{~N} & \mathrm{NC} & \end{array}$

${ }^{a_{\text {The }}} \mathrm{pH}$ control system was implemented in the model as reported in SI.8, simulating one where the maximum $\mathrm{pH}$ value set was regulated with pure $\mathrm{CO}_{2}$ injection. ${ }^{b}$ In this scenario, the concentration of TA (expressed in $\mathrm{mol} \mathrm{m}^{-3}$ ) in the influent was increased. ${ }^{c} \mathrm{NC}$ : no $\mathrm{pH}$ control.

high $\mathrm{k}_{\mathrm{L}}$ a value was estimated for the $56-\mathrm{m}^{2}$ pond used to calibrate the ALBA model, ${ }^{23}$ in line with other studies at similar scale. ${ }^{43-45}$ The second value, $\mathrm{k}_{\mathrm{L}} \mathrm{a}=0.5 \mathrm{~d}^{-1}$, represents a condition of reduced mass transfer. This lower $\mathrm{k}_{\mathrm{L}}$ a value represents poor agitation with limited atmospheric gas exchange that is typical of either full-scale ponds or raceway reactors provided with alternative mixing systems (such as submerged propellers), that guarantee appropriate mixing while minimizing the gas transfer. ${ }^{46}$ This lower value has also been recorded for raceway channels and shallow ponds. ${ }^{47-49}$

2.4. System Performance Criteria. The raceway performances were assessed based on the resulting algal biomass productivity and nutrient removal rates (ammoniacal nitrogen and orthophosphates) (Figure 7), computed as:

$$
\begin{aligned}
& \mathrm{ALG}_{\text {productivity }}\left[\mathrm{gTSS} \mathrm{m}^{-2} \mathrm{~d}^{-1}\right]: \frac{X_{\mathrm{ALG}} \cdot Q_{\text {out }}}{S} \cdot 0.64 \\
& \text { Apparent } \mathrm{TAN}_{\text {removal_rate }}\left[\mathrm{gN} \mathrm{m}^{-2} \mathrm{~d}^{-1}\right]: \frac{Q_{\text {in }} \cdot \mathrm{TAN}_{\mathrm{in}}-Q_{\text {out }} \cdot \mathrm{TAN}_{\text {out }}}{S} \\
& \quad: \frac{Q_{\text {in }} \cdot \mathrm{TAN}_{\text {in }}-Q_{\text {out }} \cdot \mathrm{TAN}_{\text {out }}+\mathrm{QNH}_{3, \text { strip }} \cdot V}{S} \\
& P_{\text {removal_rate }}\left[\mathrm{gP} \mathrm{m}^{-2} \mathrm{~d}^{-1}\right]: \frac{Q_{\text {in }} \cdot \mathrm{SPO}_{4_{\text {in }}}-Q_{\text {out }} \cdot \mathrm{SPO}_{4_{\text {out }}}}{S}
\end{aligned}
$$

where $X_{\mathrm{ALG}}$ is the algae concentration $\left(\mathrm{gCOD} \mathrm{m} \mathrm{m}^{-3}\right) ; 0.64$ $\mathrm{gTSS}_{\mathrm{gCOD}^{-1}}$ is the conversion factor for algal biomass from COD to TSS computed from the algal stoichiometry; $Q_{\text {in }}$ and $Q_{\text {out }}\left(\mathrm{m}^{3} \mathrm{~d}^{-1}\right)$ are the inflow and outflow rates; $\mathrm{TAN}_{\text {in }}$ and TAN $_{\text {out }}\left(\mathrm{gN} \mathrm{m}^{-3}\right)$ are the ammoniacal nitrogen concentration entering and leaving the system; $\mathrm{SPO}_{4 \text { in }}$ and $\mathrm{SPO}_{4 \text { out }}\left(\mathrm{gP} \mathrm{m}^{-3}\right)$ are the soluble $\mathrm{P}$ concentration as orthophosphate entering and leaving the system; $\mathrm{QNH}_{3, \text { strip }}\left(\mathrm{gN}-\mathrm{NH}_{3} \mathrm{~m}^{-3} \mathrm{~d}^{-1}\right)$ is the ammonia transfer rate to the atmosphere (negative term representing the ammoniacal nitrogen fraction leaving the system through stripping, see Table SI.11.7); and $S\left(\mathrm{~m}^{2}\right)$ is the raceway surface. The apparent TAN removal rate (eq 4) was estimated by accounting for the influent and effluent TAN loads in the liquid only, while the actual TAN removal rate (eq $5)$ was computed by excluding the stripped $\mathrm{N}-\mathrm{NH}_{3}$.

2.5. Alkalinity Computation. In order to clarify the role played by alkalinity, we computed the total alkalinity according to Dickson ${ }^{50}$ and Wolf-Gladow et al. ${ }^{51}$ :

$$
\begin{gathered}
\mathrm{TA}=\mathrm{HCO}_{3}{ }^{-}+2 \mathrm{CO}_{3}{ }^{2-}+\mathrm{H}_{2} \mathrm{PO}_{4}{ }^{-}+\mathrm{HPO}_{4}{ }^{2-}+2 \mathrm{PO}_{4}{ }^{3-} \\
+\mathrm{OH}^{-}+\mathrm{NH}_{3}-\mathrm{H}^{+}-\mathrm{HNO}_{2}-\mathrm{HNO}_{3}-\mathrm{H}_{3} \mathrm{PO}_{4}
\end{gathered}
$$

An extension of this formula is given in SI.9, in order to account for a digestate which would contain volatile fatty acids (VFA) and hydrogen sulfide, which can be further used for a more general plant-wide model, coupling anaerobic digestion and HRABP models.

\section{RESULTS AND DISCUSSION}

3.1. Long-Term Model Validation. The predictions of the ALBA model, and their $95 \%$ confidence intervals, were derived from the set of parameters previously calibrated ${ }^{23}$ and compared with the data from the six-month experimental campaign (Figure 2). The model performances were quantified using the TIC criterion (Table 4). The model quality score confirmed the good predicting ability of the model, considering that the model is said to be accurate for TIC values below $0.3 .^{41,52}$ For all the tested seasons, experimental data were well simulated. Only the results obtained in spring for nitrogen forms were less accurate (Figure 2A and Figure 2B). This is due to the fact that experimental data in spring mainly belong to the start-up phase, during which nitrite tends to accumulate and simulations are affected by the selection of the initial conditions. The highest accuracy is obtained for the online measurements of $\mathrm{pH}, \mathrm{DO}$, and temperature, with a total TIC of $0.05,0.15$, and 0.09 , respectively. This is probably the consequence of the calibration strategy based on these cornerstone variables.

The nychthemeral oscillations of DO (Figure 2E) are generally well captured by the model, even if the predicted extreme values sometimes differ from the measurements.

In Figure 2C, the simulated algal biomass concentration is compared with the estimates derived from the optical density at $680 \mathrm{~nm}$ (see SI.3). The overall algal trend is well predicted by the ALBA model, as confirmed by the values of the TIC criterion (0.19-0.24). During the summer period, algal biomass strongly decreased. This was due to the setting up of a shading net in the period between 30/07/16 and 24/08/ 16 , to reduce solar radiation and potential light inhibition. However, the shading-net effect was too strong and negatively affected algae growth, so that it was eventually removed. The predicted algae concentration responded markedly to these changes, and the predictions well fit the observed trend. In September, the model underestimates algal biomass, as confirmed by the higher TIC value. The observed misfit is probably partially due to the loose relationship between absorbance at $680 \mathrm{~nm}$ and algal biomass, which can vary due to photoacclimation, depending on light intensity, temperature, and nitrogen availability. ${ }^{53}$ Moreover, metagenomic analyses as well as microscopic observations (data not shown) evidenced sudden blooms of algal biomass predators (especially of Vorticellae), in particular between $20 / 6$ and 30/6, which caused a significant reduction in the algal biomass concentration. Predators' dynamics is not included in the ALBA model, and this could have caused local discrepancies. 
A)

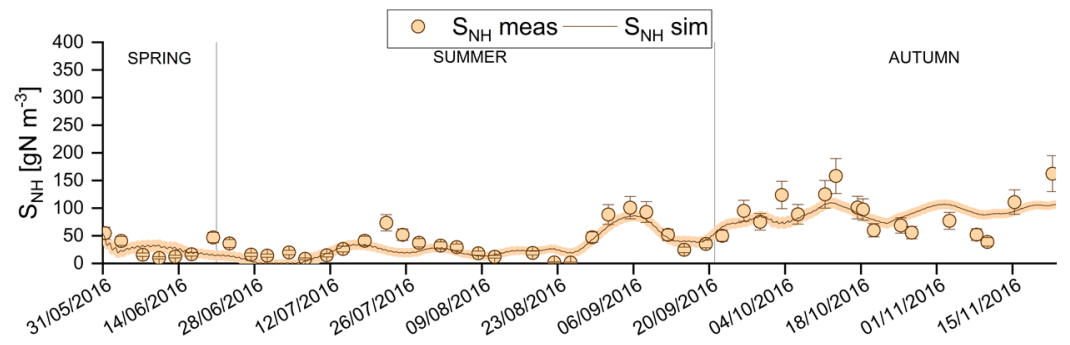

B)

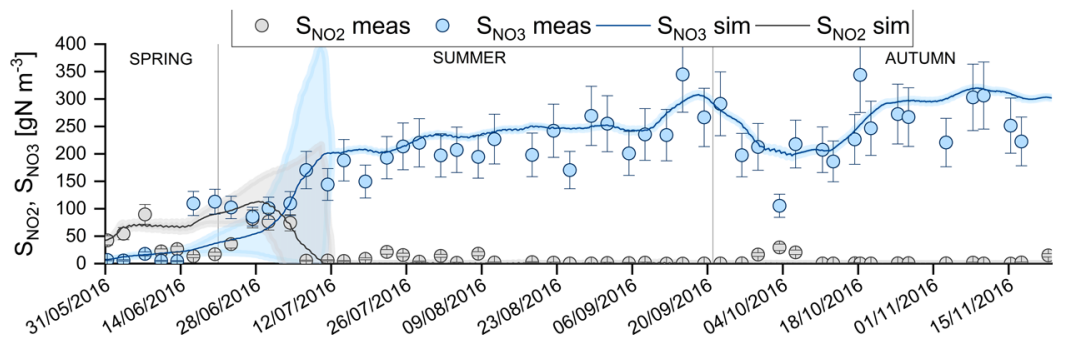

C)

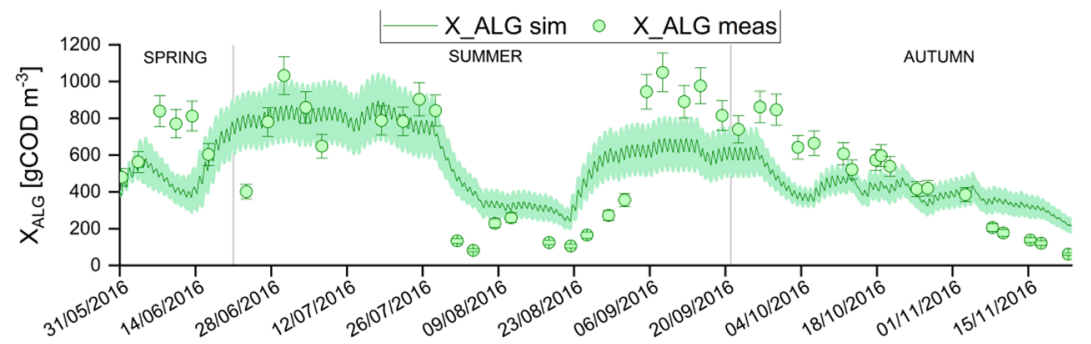

D)

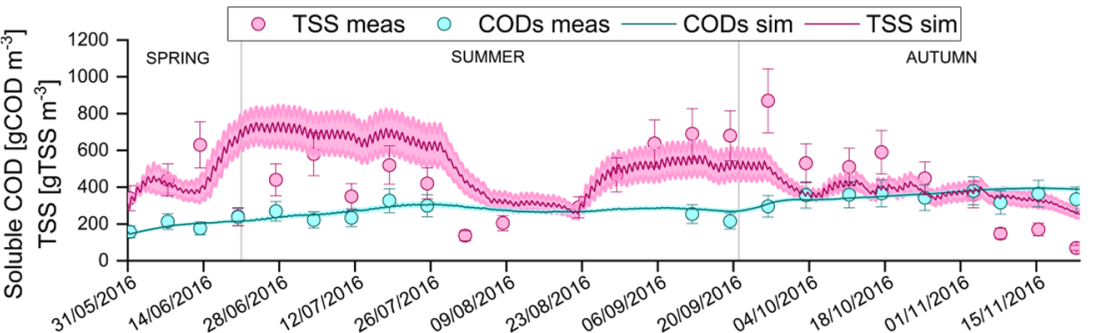

E)

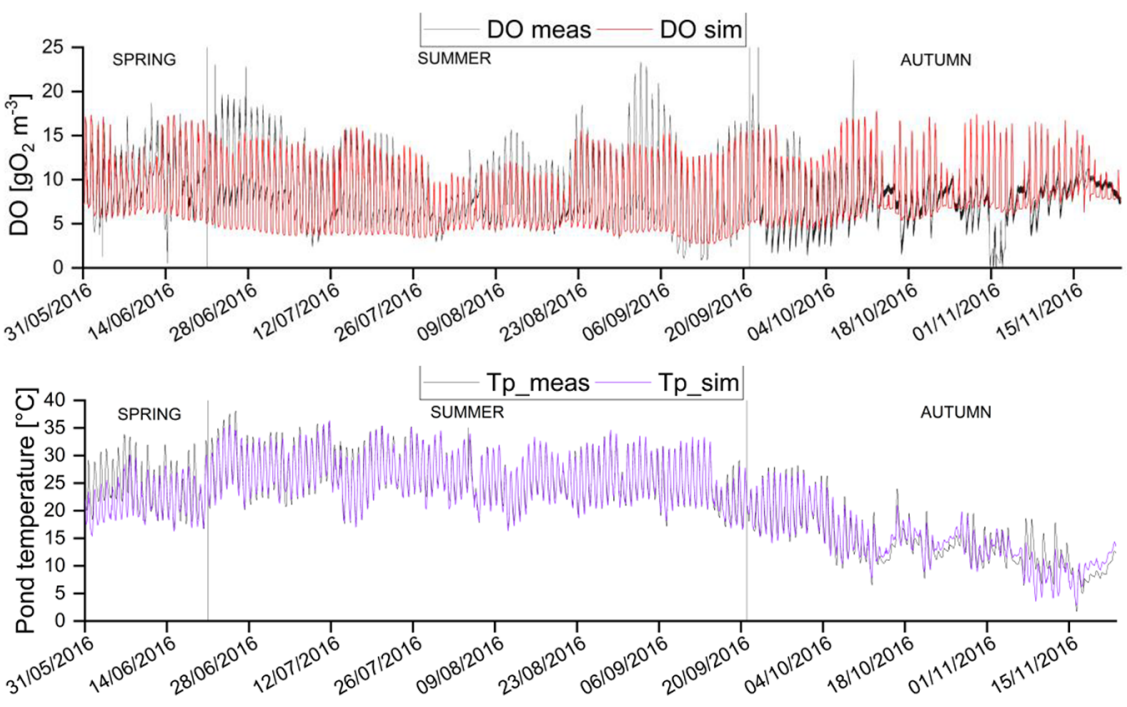

Figure 2. Long-term evolution of simulated (continuous line) versus measured values (dots): total ammoniacal nitrogen (A), nitrite and nitrate (B), algal concentration expressed in COD compared with measurements derived from optical density (C), soluble COD and TSS concentrations (D), DO (E), and temperature (F). Error bars on experimental measurements illustrate the standard deviations. Shaded areas on model predictions show the $95 \%$ confidence intervals.

Figure $2 \mathrm{~A}$ and Figure $2 \mathrm{~B}$ show the trend in nitrogen compounds. After about 20 days from the start-up, there was a switch from partial to total nitrification. Through the ALBA model, this remarkable event was effectively predicted. The same phenomenon was observed in the HRABP treating synthetic municipal wastewater that was previously used to 
Table 4. Model Efficiency Evaluated for Each Season

\begin{tabular}{lcccc} 
& \multicolumn{4}{c}{ Theil's Inequality Coefficient - TIC } \\
\cline { 2 - 5 } & Total & Spring & Summer & Autumn \\
Temperature & 0.09 & 0.09 & 0.10 & 0.10 \\
$\mathrm{DO}$ & 0.15 & 0.14 & 0.15 & 0.16 \\
$\mathrm{pH}$ & 0.05 & 0.04 & 0.04 & 0.08 \\
$\mathrm{~S}_{\mathrm{NH}}$ & 0.20 & 0.31 & 0.21 & 0.20 \\
$\mathrm{~S}_{\mathrm{NO} 2}$ & 0.34 & 0.38 & 0.30 & 0.80 \\
$\mathrm{~S}_{\mathrm{NO} 3}$ & 0.10 & 0.55 & 0.08 & 0.10 \\
$\mathrm{X}_{\mathrm{ALG}}$ & 0.20 & 0.24 & 0.19 & 0.21 \\
$\mathrm{TSS}$ & 0.21 & 0.27 & 0.18 & 0.22 \\
$\mathrm{COD}_{\mathrm{S}}$ & 0.06 & 0.07 & 0.07 & 0.05 \\
\hline
\end{tabular}

calibrate and validate the ALBA model. ${ }^{23}$ Here, complete nitrification was reached only after 70 days from start-up. The very different context of these two algal-bacterial raceways (climate, operational strategies, influent characteristics, initial nitrifying biomass) explains the difference in the time horizon to achieve the complete oxidation of the ammoniacal nitrogen. Accurately simulating the dissolved inorganic nitrogen compounds is challenging, since these variables can be affected by almost all the processes taking place in the reactor. It is also worth noting that the decrease in algal concentration during midsummer because of the presence of the shading net (Figure 2C) did not significantly affect the ammonium removal and that nitrifiers remained mainly responsible for ammonium uptake. Indeed, in the same period, temperature and $\mathrm{pH}$ were close to the optimal values for nitrifiers growth. In addition, DO has never been a limiting factor, since algal photosynthesis, together with gas/liquid mass transfer, supplied enough oxygen to support the metabolism of nitrifiers.

Moreover, the predictions for the different dissolved inorganic nitrogen compounds are in acceptable ranges. From a practical perspective, the model has therefore a good predictive ability.

It should be highlighted that the TIC value for nitrite in autumn (0.80) is artificially high due to the very low measured and simulated values. Indeed, the TIC criterion is known to amplify small model misfits when values are close to zero. ${ }^{54}$ In fact, the model predicts values which significantly differ from the measurements only for five points out of 17 . In the other seasons, TIC is always lower than 0.4 . The simulated nitrite had a yearly average of $17.8 \pm 33.8 \mathrm{~g} \mathrm{~N} \mathrm{~m}^{-3}$, while the measured nitrite was on average $14.7 \pm 23.1 \mathrm{~g} \mathrm{~N} \mathrm{~m}^{-3}$.

This overall ability of the model to capture, without any recalibration, the system dynamics can be further appreciated in SI.14 (correlation between measurements and predictions, residuals analysis).

In summary, the model efficiently predicts both qualitatively and quantitatively the observations. This evidence demonstrates the model's sound prediction capability.

A)
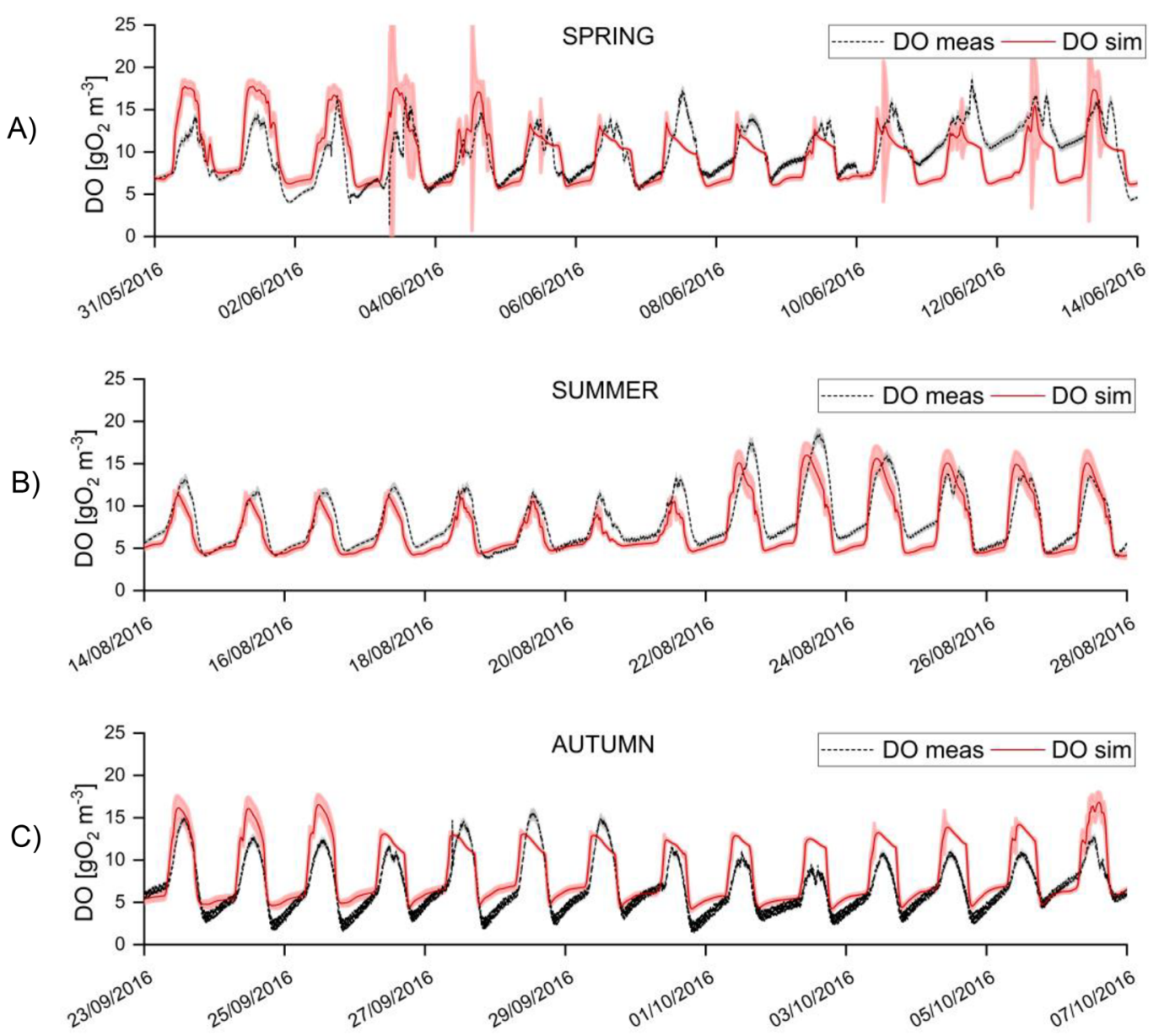

Figure 3. Short-term model validation: measured and simulated oxygen trend in spring (A), summer (B), and autumn (C). Gray shaded areas represent the standard deviation of DO online measurement. Red shaded areas represent the $95 \%$ confidence intervals of model predictions for DO. 


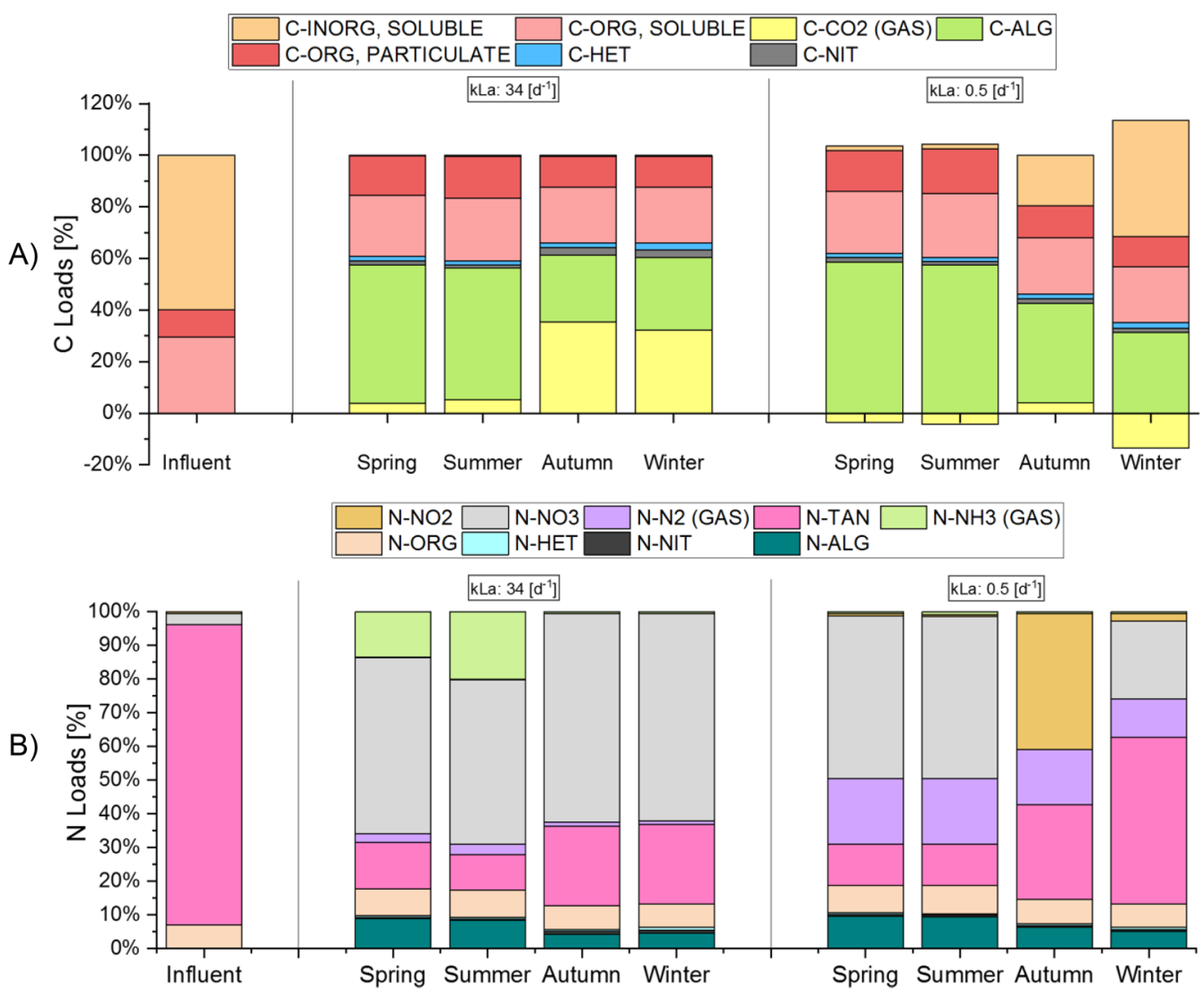

Figure 4. Percentage of influent and effluent carbon (A) and nitrogen (B) fluxes, under normal and reduced mass transfer conditions $\left(S 1, k_{L} a=34\right.$ $\mathrm{d}^{-1}$ and $\left.\mathrm{S} 2, \mathrm{k}_{\mathrm{L}} \mathrm{a}=0.5 \mathrm{~d}^{-1}\right)$. The S1 and S2 scenarios were analyzed according to seasons: spring, summer, autumn, and winter. In Figure 4A, CORG, PARTICULATE is the organic carbon present in $X_{\mathrm{S}}$ and $X_{\mathrm{I}}$ fractions; C-ORG, SOLUBLE is the organic carbon present in $S_{\mathrm{S}}$ and $S_{\mathrm{I}}$ fractions; C-ALG, C-NIT, and C-HET are the organic fractions present in the algal, nitrifying (AOB and NOB) and heterotrophic biomass, respectively. In Figure 4B, N-ORG is the organic nitrogen present in $X_{\mathrm{S}}, X_{\mathrm{I}}, S_{\mathrm{S}}$, and $S_{\mathrm{I}}$ fractions; N-ALG, N-NIT, and N-HET are the organic nitrogen fractions present in the algal, nitrifying ( $\mathrm{AOB}$ and $\mathrm{NOB}$ ) and heterotrophic biomass, respectively. The computed fluxes of $\mathrm{N}_{2}, \mathrm{NH}_{3}$ and $\mathrm{CO}_{2}$ are gaseous, while all other are liquid fluxes.

3.2. Ecosystem Structure. A close look at the simulated dynamics of the involved microorganisms definitely confirms a structurally different system. To better identify the behavior of the system under consistently different conditions, the fractionation of the total biomass concentration was calculated by taking advantage of the capability of the ALBA model to predict the concentrations of the algal, heterotrophic, and nitrifying populations. Indeed, one of the most difficult aspects in mixed algae-bacteria systems is to experimentally determine the evolution of bacterial populations, since the quantification of the algal biomass is generally the only available measurement in the microbial community. Therefore, the percentage of each microbial guild on the overall biomass was computed. This result was compared with the microbial community composition simulated by the ALBA model. ${ }^{23}$ In the study reported in Casagli et al., ${ }^{23}$ the HRABP was fed on synthetic urban wastewater, and microalgae were $76.8 \%$ of the biomass, heterotrophs were $21.8 \%$, and nitrifiers were $1.4 \%$, on average. In the current case study, the total biomass concentration was similar, but nonetheless, the composition was significantly different. Indeed, microalgae dominate $(90.2 \%)$ the microbial community, while heterotrophs and nitrifiers are found in similar proportions $(3.8 \%$ and $6.0 \%$ on average, respectively, see Figure SI.6.1A,B). Therefore, the ecosystem is definitely more autotrophic. Specifically, model simulations revealed that the $\mathrm{AOB}$ percentage on the total biomass was $4.9 \pm 3.7 \%$, and these predictions match the measurements $(2.8 \pm 1.7 \%)$ carried out by Mantovani et al..$^{6}$ on a similar raceway located in the same area and processing digestate.

3.3. Model Universality for Significantly Different Conditions. Validating the model for a different case study (treating different wastewater with $\mathrm{pH}$ regulation and different climate) without modifying the set of parameters is definitely challenging and not at all straightforward.

The ALBA model could be better tailored to the current case study. For instance, some improvements could be achieved by tuning parameters affected either by the microbial composition (i.e., the light extinction coefficient) or by the process design (typically the $k_{L} a$ ). Also, the parameters could be adapted to seasonal variability to track the changes in the microbial community evolution.

However, the quality of its performance does not motivate any further fine-tuning utilizing the data from the monitoring campaign, demonstrating the universality of the ALBA model and its parameters.

3.4. Short-Term Oxygen Dynamics. In Figure 3, two selected weeks from the data set are shown in order to better appreciate the daily dynamics of DO in different seasons. In general terms, the model provided a very good agreement with experimental values. It can be observed that the model is able to follow the day/night cycles and that DO concentrations are 


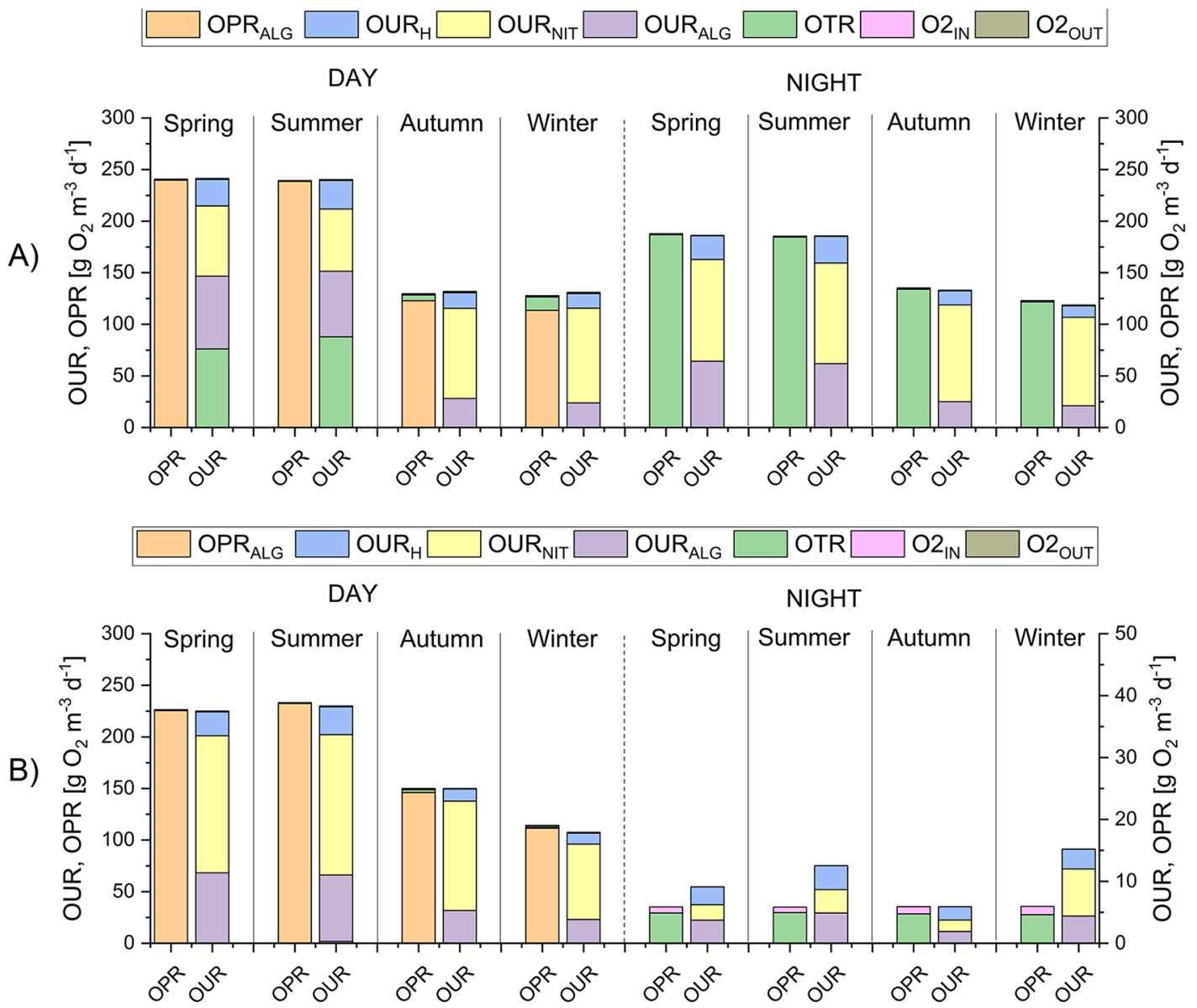

Figure 5. Oxygen production rate $\left(\mathrm{OPR}_{\mathrm{ALG}}\right)$, oxygen transfer rate $(\mathrm{OTR})$, and oxygen consumption rates $\left(\mathrm{OUR}_{\mathrm{ALG}}, \mathrm{OUR}_{\mathrm{NIT}}, \mathrm{OUR}_{\mathrm{H}}\right)$ under two gas-liquid mass transfer conditions: A) scenario $\mathrm{S} 1, \mathrm{k}_{\mathrm{L}} \mathrm{a}=34 \mathrm{~d}^{-1}$ and $\mathrm{B}$ ) scenario $\mathrm{S} 2, \mathrm{k}_{\mathrm{L}} \mathrm{a}=0.5 \mathrm{~d}^{-1}$. S1 and S2 scenarios were analyzed according to each season and day (left axis)-night (right axis) cycles.

effectively predicted during each season. This also occurs in the summer, when the shading net was applied.

The 95\% confidence interval on model predictions is wider in the cloudy days in spring, as it is also confirmed by the recorded DO oscillations. This phenomenon highlights the sensitivity of the photosynthesis model to fast change in light intensity due to the clouds.

It is also interesting to notice that at night, when DO is only consumed by respiration, DO concentration increases, as observed in similar open systems. ${ }^{23,55}$ This apparently counterintuitive phenomenon, that the model was able to capture, is mainly due to the oxygen exchange with the atmosphere, that is enhanced at night by the increased oxygen solubility at lower temperatures. This results in a sufficient DO supply to support aerobic processes at night, i.e., the algal and bacterial respiration, which are, in turn, slowed down at lower temperatures. The occurrence of anoxic processes at night was avoided by the high reaeration rate provided by the paddle wheel (see Figure 2E), as it is generally the case with HRABPs. ${ }^{2}$ Indeed, at industrial scale (and lower $\mathrm{k}_{\mathrm{L}} \mathrm{a}$ ), lower oxygen concentration would be reached during the night.

3.5. Carbon, Nitrogen, and Oxygen Fluxes in the System. The validated ALBA model is a powerful tool to provide deep insights into the hidden mechanisms behind this complex dynamic system. A typical operating scenario was simulated (scenario S1, HRT $=10 \mathrm{~d}, \mathrm{pH}$ set point $=7.5, \mathrm{k}_{\mathrm{L}} \mathrm{a}=$ $34 \mathrm{~d}^{-1}$ ) considering each seasonal condition. To better understand the role played by oxygen as exchange money between the various microorganisms in the ecosystem, ${ }^{23}$ an alternative system for mixing was simulated using a propeller, ${ }^{46}$ that would result into appropriate mixing but reduced gas exchanges with the atmosphere and eventually a lower masstransfer coefficient $\left(\mathrm{k}_{\mathrm{L}} \mathrm{a}=0.5 \mathrm{~d}^{-1}\right)$. The seasonal periodic regime (see section 2.3, Figure 1) was used to estimate the fluxes of carbon, nitrogen, and oxygen in the system. The partitioning of carbon and nitrogen among the different components in the inflow and outflow (expressed in percentage of the total liquid inflow) is reported in Figure 4. Figure 4A shows that, for this operating scenario, a large fraction of the carbon leaves the system as algal biomass, especially in spring and summer. The $\mathrm{C}$ fraction in the algal biomass is reduced in autumn and winter, as a consequence of the lower temperature and irradiance (Figure 1). The marked reduction in algal growth during these cold and low irradiance seasons leads to a decrease in the flux of $\mathrm{CO}_{2}$ uptake by photosynthesis. In spring and summer, a very low flow of $\mathrm{CO}_{2}$ is emitted, while $\mathrm{CO}_{2}$ emission accounts for $30 \%$ of the carbon entering the system in winter. The influent and effluent organic fractions are similar, since they are hardly affected by seasonal variability. Coming from an anaerobic digestion process, the majority of the organic $\mathrm{C}$ in the influent is inert (both for the soluble and particulate forms) and leaves the system without being chemically or biologically transformed. 
In this alternative $\mathrm{S} 2$ scenario (Figure $4 \mathrm{~A}$ ), the main carbon outflow is still due to algal biomass, similar to the reference case. This outflow is slightly higher compared to the reference case and less $\mathrm{CO}_{2}$ is emitted, especially in the colder seasons, as the system becomes even a net $\mathrm{CO}_{2}$ consumer. While a $\mathrm{CO}_{2}$ fraction is stripped in the scenario $S 1\left(\mathrm{k}_{\mathrm{L}} \mathrm{a}=34 \mathrm{~d}^{-1}\right)$, it remains in the bulk under low $\mathrm{k}_{\mathrm{L}}$ a, so that more inorganic carbon is available for algal growth during the day. In autumn and winter, a larger amount of dissolved inorganic carbon leaves the system because of the overall lower algal and nitrifying activities compared to warmer conditions. However, when considering total liquid and gaseous inorganic carbon outflows, the two scenarios are not so different. This could mean that gas exchange induced by the mixing system is not strongly affecting carbon conversion.

The fluxes of oxygen in the system (separated into oxygen production rates, OPRs, and oxygen uptake rates, OURs) are given in Figure 5, distinguishing between day and night periods. Under the operating conditions S1 (Figure 5A), the oxygen production during the day is always sufficient to sustain the oxygen requirements due to the algal respiration and the bacterial activity, with a significant fraction of oxygen being wasted through stripping. The OPR is quite high in spring and summer, with a significant reduction in the cold seasons. The OUR of nitrifying bacteria is always higher than that of heterotrophic bacteria, coherently with the typically high TAN loads and the low levels of degradable carbon in digestates. ${ }^{56,57}$ The contribution of nitrifiers to the overall OUR is even larger in autumn and winter, further confirming that these microorganisms succeed in carrying out the TAN oxidation under cold conditions, also supported by the additional $\mathrm{CO}_{2}$ provided by the $\mathrm{pH}$-control system. At night, the main oxygen input comes from liquid/gas transfer provided by the paddle wheel, thus supporting the algal and bacterial respiration.

With the S2 scenario simulating a mixing system with lower liquid/gas transfer (Figure 5B), the OPR is not particularly affected during the day, with values similar to the standard case. On the contrary, the nitrifying activity is highly enhanced in spring and summer, since more inorganic carbon and DO accumulate in the system, as they cannot be fastly transferred to the atmosphere. At night, however, the overall flow rates are reduced by at least one order of magnitude, while DO drops to zero for almost all the night because it is too slowly refueled from the atmosphere.

The different outflows of nitrogen are shown in Figure 4B. With paddle wheel standard operating conditions (S1), most of the nitrogen is oxidized to nitrate, evidencing the favorable conditions for the development of an algae-nitrifiers' consortium. Nitrification is also active in cold seasons, thus contributing to maintain high TAN removal efficiencies all over the year. However, the unconverted TAN increases in winter, due to the reduced nitrifiers' activity. Even if the nitrifying biomass is always lower than $10 \%$ of the algal biomass, the TAN fraction assimilated by the algae remains low all over the year, and approximately $56 \%$ of the TAN conversion route is via nitrification, on a yearly average. It should be noticed that, in spring and summer, the ammonia stripped from the pond can reach up to $20 \%$ of the influent load, while in the other seasons it is much less marked. This high $\mathrm{NH}_{3}$ emission has a strong environmental impact in terms of both eutrophication and greenhouse gas (GHG) emissions. ${ }^{58}$ This undesirable emission disappears when $\mathrm{k}_{\mathrm{L}} \mathrm{a}$ decreases. In this case, a significant fraction $(35-70 \%$ of the influent load) is still nitrified. However, due to a combination of temperature and DO limitation at night, that are unfavorable conditions for NOB, only a partial nitrification occurs in autumn, with nitrite being the largest fraction of the outflow nitrogen load. Algal activity is lower in autumn because of the reduced irradiance compared to winter (Figure 1). The larger outflow of molecular nitrogen at low $\mathrm{k}_{\mathrm{L}} \mathrm{a}$ is due to the fact that DO drops to zero at night, making the anoxic growth of heterotrophic bacteria possible.

3.6. Can Algae and Nitrifiers Work Together without the Risk of $\mathrm{N}_{2} \mathrm{O}$ Production? Avoiding inorganic carbon limitation is necessary for optimizing biomass productivity and nutrient removal rates. ${ }^{59,60}$ Working at $\mathrm{pH}$ below 7.5 is, in principle, well-known to guarantee that $\mathrm{CO}_{2}$ is not limiting the algal growth ${ }^{59,61}$ and nitrifiers' activity. ${ }^{62}$ The model reveals that this statement does not hold here. Indeed, a closer look at alkalinity (SI.9) shows a regular drop caused by the consumption of ammonium as well as by the production of nitrate and nitrite. Influent alkalinity was $30 \mathrm{~mol} \mathrm{~m}^{-3}$, which is too low to support the full nitrification by autotrophic bacteria, as it has often been described for digestate. ${ }^{63}$ When the system reaches a very low alkalinity $\left(0.40 \pm 0.23 \mathrm{~mol} \mathrm{~m}^{-3}\right.$, on average, according to eq 7), it no longer allows bicarbonate storage in solution, and the level of dissolved inorganic carbon remains dramatically low (see Figure SI.9.1). In all the simulated scenarios in which the $\mathrm{pH}$ was lower than 7.5 (and with HRTs that do not lead to biomass washout), the simulated concentration of inorganic carbon remained very low (below $8 \mathrm{gC} \mathrm{m}^{-3}$, see tables in SI.10) and resulted in the limited growth of autotrophic and photoautotrophic populations. Under these conditions, a strong competition for inorganic carbon takes place between the algae and the nitrifiers. The outcome of this competition, which also depends on other environmental (light and temperature) and chemical (DO, $\mathrm{pH}$, and alkalinity) factors, contributes to defining the biomass distribution and the system dynamics. ${ }^{64,65}$ This analysis shows that inorganic carbon and alkalinity should be considered as key parameters to be controlled, especially in algae-bacteria systems, where the algal population dominates the system.

Conditions of inorganic carbon limitation have been shown by several authors to enhance cellular maintenance energy of nitrifiers and become favorable for the production of $\mathrm{N}_{2} \mathrm{O}$. ${ }^{66,67}$ A wide range of microbial mechanisms has been identified as favoring $\mathrm{N}_{2} \mathrm{O}$ production in nitrifying systems, being chiefly dependent on environmental conditions and on the chemical characterization of the medium. ${ }^{68,69} \mathrm{~N}_{2} \mathrm{O}$ production by nitrifiers was studied by Mellbye et al. ${ }^{67}$ who observed a 6.3fold increase when inorganic carbon became highly limiting. It is thus of utmost importance to identify the working conditions which are likely to give rise to a marked inorganic carbon limitation.

Although mechanistic models of $\mathrm{N}_{2} \mathrm{O}$ production already exist, ${ }^{70}$ further studies would be necessary to integrate the set of complex conditions triggering $\mathrm{N}_{2} \mathrm{O}$ emissions into a predictive model and to validate it under outdoor conditions. While developing a model able to represent the production of $\mathrm{N}_{2} \mathrm{O}$ and integrate it into the ALBA model is beyond the objectives of this work, the ALBA model can definitely help in identifying the critical working conditions associated with $\mathrm{N}_{2} \mathrm{O}$ production. The accurate modeling of the interplay between the chemical species driving the $\mathrm{pH}$ dynamics was used to evaluate the periods of strong inorganic carbon limitation, which have been shown to trigger $\mathrm{N}_{2} \mathrm{O}$ emissions, i.e., when 


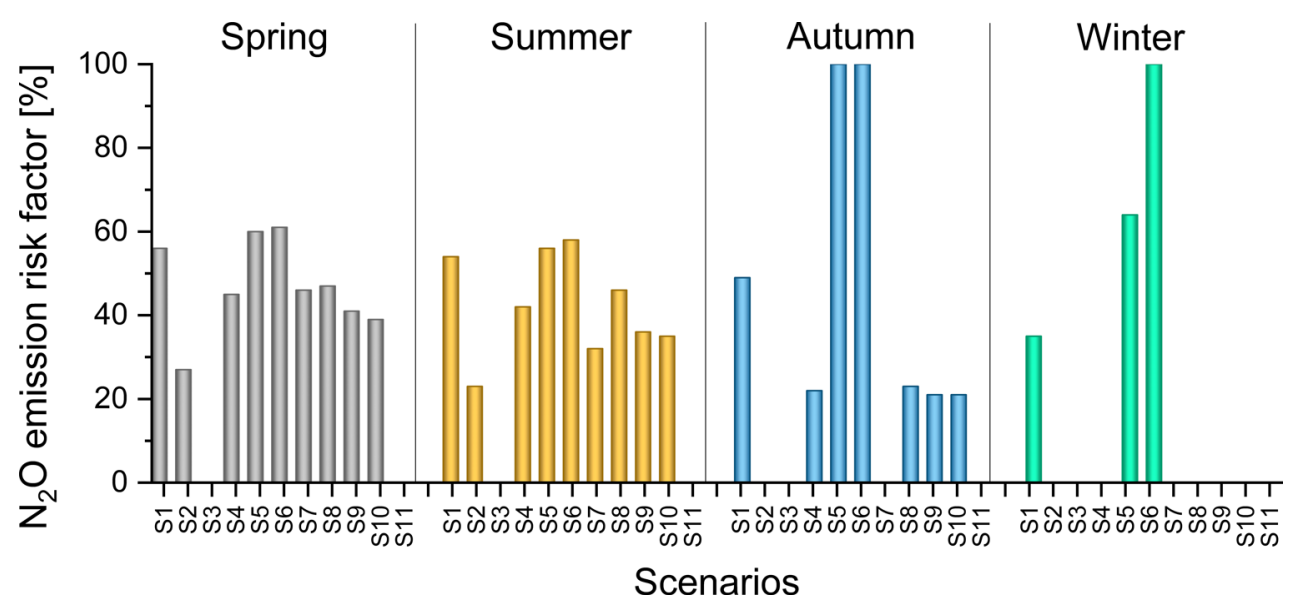

Figure 6. $\mathrm{N}_{2} \mathrm{O}$ emission risk factor (percentage of time along the day for which $\mathrm{N}_{2} \mathrm{O}$ formation conditions occur, i.e., inorganic carbon $<0.2$ molC $\mathrm{m}^{-3}$ ), according to the season.

the total inorganic carbon drops below $0.2 \mathrm{~mol} \mathrm{~m}^{-3}$, as suggested by Mellbye et al. ${ }^{67}$ The model therefore provides a risk index of $\mathrm{N}_{2} \mathrm{O}$ emissions (Figure 6), quantified as the percentage of time under which the system was likely to favor the bacterial $\mathrm{N}_{2} \mathrm{O}$ production. On the basis of this risk index quantification, the above investigated scenarios ( $\mathrm{S} 1$ and $\mathrm{S} 2$ ) are associated with a high risk of $\mathrm{N}_{2} \mathrm{O}$ emission, especially in summer and spring, with more than $40 \%$ of the time operating under inorganic carbon limitation. The next paragraph investigates optimization strategies, so as to maximize the HRABP efficiency while avoiding operating under these dangerous conditions.

3.7. Can Raceway Performances Be Optimized Keeping Gaseous Emissions Low? The ALBA model was used to explore the impact of different working conditions, simultaneously evaluating their effect on the gaseous emissions that are likely to have high environmental impacts $\left(\mathrm{CO}_{2}, \mathrm{NH}_{3}\right.$, $\mathrm{N}_{2} \mathrm{O}$ ) and on conventional efficiency parameters (algal productivity, nutrient removal). In a first stage, operating parameters classically used at industrial scale (HRT and $\mathrm{pH}$ control set point) were considered.

3.7.1. Classical Operating Management with HRT and $p H$. Various scenarios were run exploring different combinations of HRT and $\mathrm{pH}$ (S3 to S10, Table 3), in order to show how these operational parameters can shape the ecosystem. Results are shown in Figure 7 (see all the tested conditions in SI.10). The algal biomass productivity (Figure 7A and Figure 7B) is strongly affected by the HRT. More specifically, by maintaining a 2-day HRT, productivity can reach values up to 22 and 21 gTSS m $\mathrm{m}^{-2} \mathrm{~d}^{-1}$ in spring and summer, respectively. However, such a dilution rate leads to the washout of the algal biomass in winter, causing $\mathrm{N}$ and $\mathrm{P}$ removal rates to drastically drop (Figure 7C and Figure 7E). The best algal biomass productivity in autumn and winter is obtained for a 5-day HRT, with 8.5 gTSS $\mathrm{m}^{-2} \mathrm{~d}^{-1}$. Playing with $\mathrm{pH}$ resulted in a marginal effect only (Figure $7 \mathrm{~B}$ ), and it was used to further tune the optimal working modes.

It is worth noticing that the conditions optimizing algal productivity also maximize nutrient removal rates (Figure $7 \mathrm{C}$ and Figure $7 \mathrm{E}$ ). For TAN, the apparent removal rate is in the range of 20 to $24 \mathrm{gN}-\mathrm{NH}_{4}^{+} \mathrm{m}^{-2} \mathrm{~d}^{-1}$ in spring and summer at $\mathrm{HRT}=2 \mathrm{~d}$, while it drops to $10-13 \mathrm{gN}-\mathrm{NH}_{4}{ }^{+} \mathrm{m}^{-2} \mathrm{~d}^{-1}$ in autumn and winter at 5-day HRT. For phosphorus, it ranges

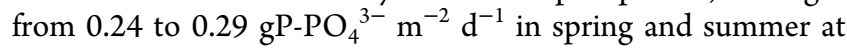

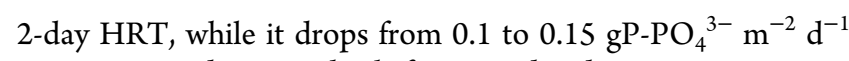
in autumn and winter, both for 2- and 5-day HRT.

Regulating $\mathrm{pH}$ at 7.5 seems a good trade-off to minimize the $\mathrm{CO}_{2}$ injection cost-even if $\mathrm{CO}_{2}$ can be recovered after biogas upgrading - while keeping a high algal productivity. In autumn and winter, $\mathrm{pH} 8$ or even unregulated $\mathrm{pH}$ are appropriate, which will be the best solution from an economic point of view.

Atmospheric emissions must be considered in the optimization strategy to make sure that the process would be sustainable from an environmental point of view. The ALBA model was used to assess the flux of $\mathrm{NH}_{3}$ which is stripped to the atmosphere. In this view, a lower $\mathrm{pH}$ is highly recommended, especially in spring and summer when algal activity is higher, so that TAN mostly remains under the ammonium form and the undesirable flux of $\mathrm{NH}_{3}$ toward the atmosphere is strongly reduced (from $2-3 \mathrm{gN}^{-N_{3}} \mathrm{~m}^{-2} \mathrm{~d}^{-1}$ at $\mathrm{pH}$ higher than 7.5 to $0-0.08 \mathrm{gN}^{-\mathrm{NH}_{3}} \mathrm{~m}^{-2} \mathrm{~d}^{-1}$ at $\mathrm{pH}$ lower than 7.5, see SI.10). The actual nitrogen removal rate was also computed excluding stripping from the pond. This significantly changes the picture. For instance, looking closer at the fraction of the different populations in the system (see Figure $7 \mathrm{G}$ ) for a low HRT, nitrifiers are washed out from the system. Ammonium is only consumed by algae at a much lower rate, and the actual TAN removal rate is finally very low. This is the reason why inorganic carbon was not limiting in these regimes, i.e., the low nitrification did not exert any pressure on it.

The way to consider the flux of $\mathrm{CO}_{2}$ emitted from the respiration processes of algae and bacteria is debatable since it is of biogenic origin. The emissions of the $\mathrm{CO}_{2}$ from the $\mathrm{pH}$ regulation system can be of fossil origin-if not recycled from the biogas, and more clearly contribute to greenhouse gas emissions. In any case, only an in-depth LCA study ${ }^{71,72}$ can accurately identify the process impact on climate change, but for sure it will be strongly dependent on the emission of gases such as $\mathrm{NH}_{3}$ and $\mathrm{N}_{2} \mathrm{O}$. These emissions can be strongly reduced by correctly managing the HRABP, as it is discussed in the next section.

3.7.2. Introducing Alkalinity in the Management Strategy. Finding a working mode balancing conventional efficiency parameters and atmospheric emissions is however challenging. The conditions maximizing both algal productivity and removal rates put pressure on the inorganic carbon stock, hence leading to the high risk of $\mathrm{N}_{2} \mathrm{O}$ production. The risk of 
A)
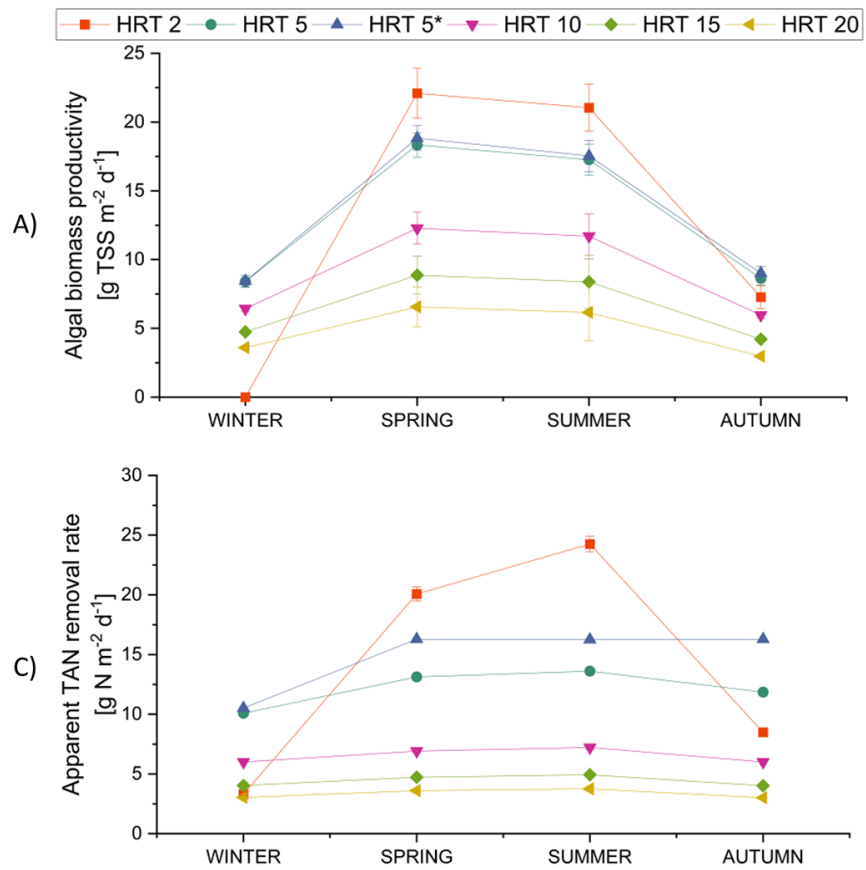

E)
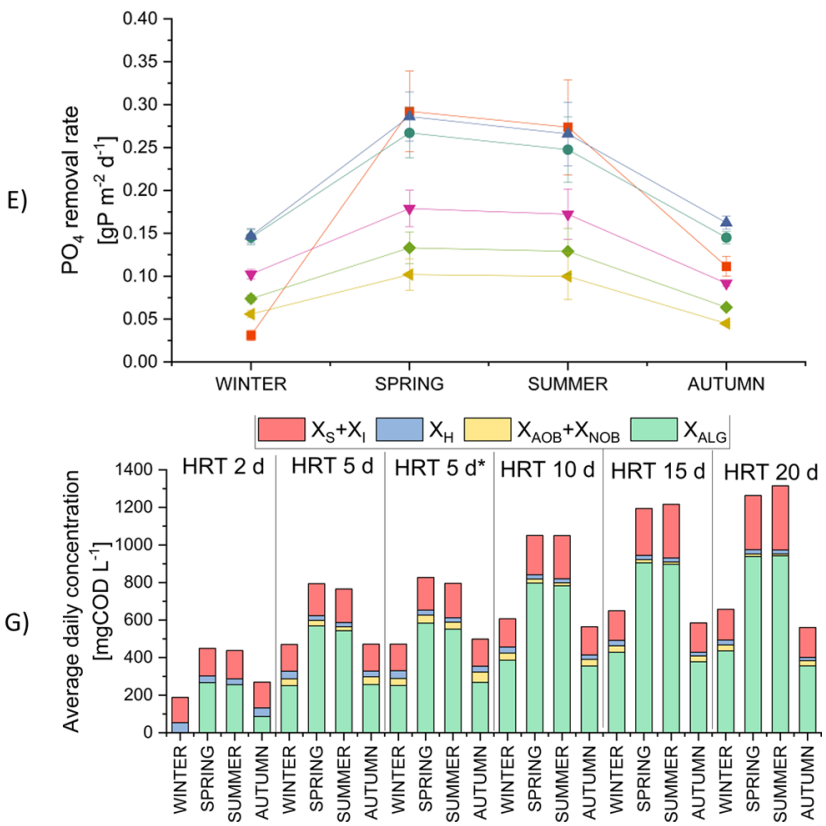

B)

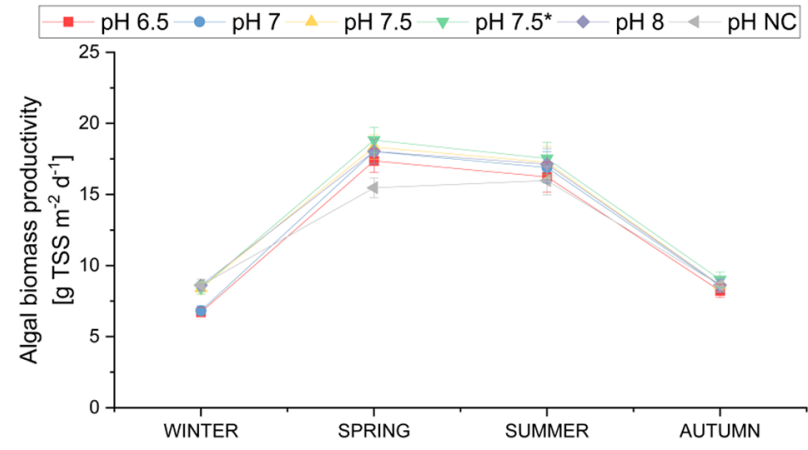

D)

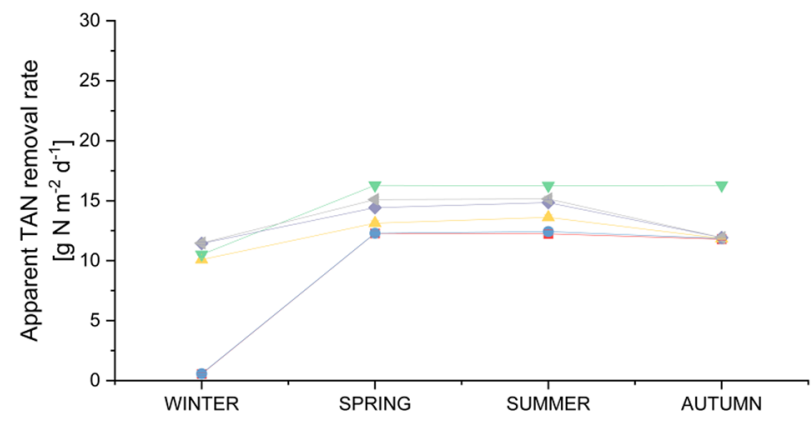

F)

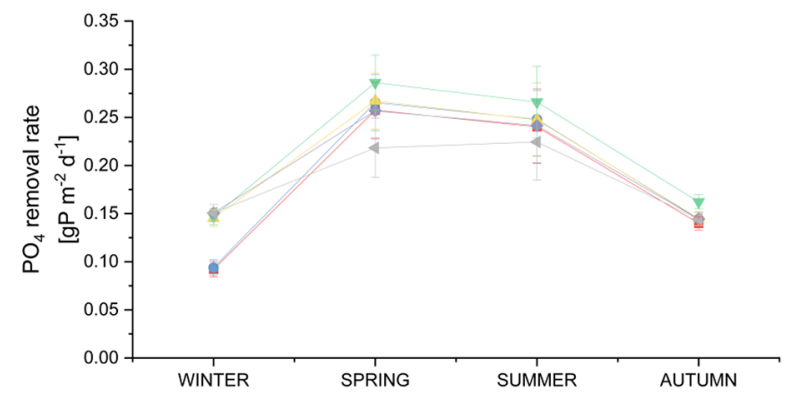

H)

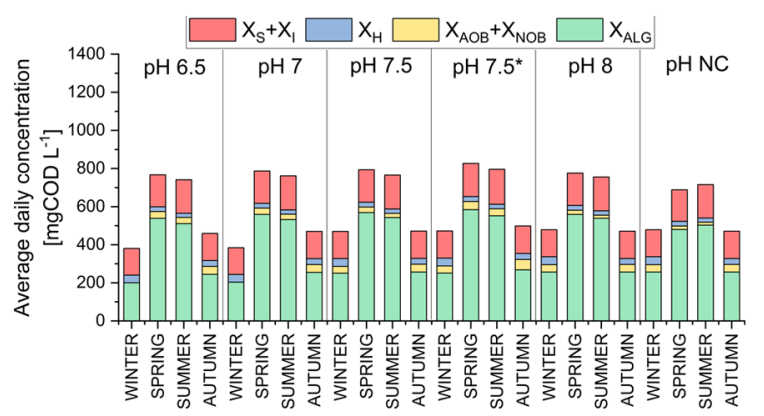

Figure 7. Effects of $\mathrm{pH}$ and HRT variation on the algae-bacteria cultivation in terms of the following: algal biomass productivity (A: HRT variation, $\mathrm{B}: \mathrm{pH}$ variation), apparent TAN removal rate (C: HRT variation, $\mathrm{D}: \mathrm{pH}$ variation), orthophosphate removal rate (E: HRT variation, F: $\mathrm{pH}$ variation), and TSS percentage fractionation (G: HRT variation, $\mathrm{H}: \mathrm{pH}$ variation). $\mathrm{X}_{\mathrm{S}}$ is the particulate slowly biodegradable organic matter, while $\mathrm{X}_{\mathrm{I}}$ is the particulate inert organic matter. Simulations at different HRTs were run at a pH set point of 7.5 (scenarios S1, S3-S6, S11), while simulations at different $\mathrm{pH}$ set points were run with HRT $=5 \mathrm{~d}$ (scenarios S4, S7-S11).

$\mathrm{N}_{2} \mathrm{O}$ production appeared in all the scenarios (SI.10 and Figure 6), except for scenario S3, where nitrifiers are washed out of the system resulting in poor actual nitrogen removal. Spring and summer were the most affected seasons, and none of the classical operating conditions could avoid limitation by inorganic carbon for at least $30 \%$ of the time. In the scenarios where a low $\mathrm{k}_{\mathrm{L}}$ a was set (SI.2 and SI.4.1, also SI.10), the inorganic carbon limitation and the risk of $\mathrm{N}_{2} \mathrm{O}$ production were strongly reduced.

Subsequently, another scenario was considered and run under the same conditions set for scenario S4 but with influent alkalinity increased by $20 \mathrm{~mol} \mathrm{~m}^{-3}$ (named S11). The idea was to counterbalance the low alkalinity level responsible for the very low soluble inorganic carbon concentration despite $\mathrm{pH}$ regulation.

Under S11 conditions, the percentage of time for which $\mathrm{N}_{2} \mathrm{O}$ formation can occur drops to zero. In addition, in all the seasons, $\mathrm{CO}_{2}$ emissions are consistently lowered thanks to the higher capacity to store inorganic carbon in the system, as confirmed by the higher concentration of dissolved inorganic carbon (above $100 \mathrm{~mol} \mathrm{~m}^{-3}$, see SI.10). Simulations show that this scenario outcompetes most of the other scenarios and simultaneously maximizes the algal biomass production and nutrient removal. Moreover, the actual TAN removal rate 
increases since the inorganic carbon is no longer limiting as it was in S4. This finding shows that nitrifiers suffer from the competition for the available inorganic carbon under alkalinitylimiting conditions.

Alkalinity was revealed to be a hidden process parameter that must be definitely controlled to operate the system under optimal conditions and alkalinity addition is definitely a way to enhance the system performances.

An economic analysis with $\mathrm{NaOH}$ addition to regulate alkalinity was performed (see details of hypotheses and computations in SI.15). Treating an additional 30\% of nitrogen (scenario S11 compared to S4), with additional alkalinity, has an estimated value of $0.03 \$ \mathrm{~m}^{-2} \mathrm{~d}^{-1}$, computed on the basis of an operational cost for treating nitrogen of $6 \$ \mathrm{kgN}^{-1}$. ${ }^{73}$ The cost of alkalinity addition is $0.0128 \$ \mathrm{~m}^{-2} \mathrm{~d}^{-1}$, which is definitely counterbalanced by the value associated with the increase in nitrogen treatment efficiency. Therefore, alkalinity addition does make sense even from an economic point of view.

3.7.3. Toward Advanced Process Control. The process optimization must be further explored considering a more complex problem with an efficiency criterion that combines algal production, nutrient removal rate, atmospheric emissions $\left(\mathrm{NH}_{3}, \mathrm{CO}_{2}, \mathrm{~N}_{2} \mathrm{O}\right)$, and associated costs by simultaneously playing with alkalinity and the standard operating parameters (HRT, $\mathrm{k}_{\mathrm{L}} \mathrm{a}$, $\mathrm{pH}$ set point).

An advanced control problem similar to the one targeted in the work of de Luca et al. ${ }^{37}$ will help identify the optimal operational mode hourly adapted to the metereological conditions and online adjustment of the operational parameters. The ALBA model can now be used as a solid tool for process optimization while limiting emissions toward the environment.

\section{ASSOCIATED CONTENT}

\section{(s) Supporting Information}

The Supporting Information is available free of charge at https://pubs.acs.org/doi/10.1021/acs.est.0c05264.

SI.1: schematic representation of the raceway pond; SI.2: evaluation of experimental measurements' standard deviations; SI.3: correlation between optical density at $680 \mathrm{~nm}$ and Total Suspended Solids concentration; SI.4: weather data set used in this study; SI.5: effect of temperature on the dissolved oxygen profile; SI.6: fractionation of the total biomass into algal and bacterial fractions; SI.7: calibration and validation of the temperature submodel; SI.8: description of the $\mathrm{pH}$ control implementation in the model; SI.9: computation of alkalinity and its effect on inorganic carbon availability; SI.10: extended scenario analysis results; SI.11: complete description of the ALBA model; SI.12: experimental measurement of $\mathrm{k}_{\mathrm{L}} \mathrm{a}$; SI.13 parameter uncertainty and error propagation; SI.14 residual analysis; SI.15 economic computation for alkalinity addition; SI.16 references (PDF)

\section{AUTHOR INFORMATION}

\section{Corresponding Author}

Elena Ficara - Dipartimento di Ingegneria Civile e Ambientale (DICA), Politecnico di Milano, 20133 Milan, Italy; 잉o..org/0000-0002-8893-6246; Email: elena.ficara@ polimi.it

\section{Authors}

Francesca Casagli - Dipartimento di Ingegneria Civile e Ambientale (DICA), Politecnico di Milano, 20133 Milan, Italy; Institut National de Recherche en Informatique et en Automatique (INRIA), Biocore, Université Cote d'Azur, 06902 Sophia-Antipolis, France

Simone Rossi - Dipartimento di Ingegneria Civile e Ambientale (DICA), Politecnico di Milano, 20133 Milan, Italy

Jean Philippe Steyer - INRAE, Univ Montpellier, LBE, 11100 Narbonne, France

Olivier Bernard - Institut National de Recherche en Informatique et en Automatique (INRIA), Biocore, Université Cote d'Azur, 06902 Sophia-Antipolis, France

Complete contact information is available at:

https://pubs.acs.org/10.1021/acs.est.0c05264

\section{Notes}

The authors declare no competing financial interest.

\section{ACKNOWLEDGMENTS}

F.C., S.R., and E.F. wish to thank Fondazione Cariplo (project: Polo delle Microalghe) for their financial support. F.C. and O.B. benefited from the support of the ADEME BIOMSA project. The authors sincerely thank Dr. Andrea Pizzera and Dr. Nadia Margariti for their contribution in the monitoring campaign and in the laboratory, respectively. The authors thank the E-COST (European Cooperation in Science and Technology), action ES1408-European network for algalbioproducts (EUALGAE), for supporting the scientific collaboration. The authors warmly thank Dr. Lucia Zigliani for the English revision of the paper.

\section{REFERENCES}

(1) Craggs, R.; Sutherland, D.; Campbell, H. Hectare-Scale Demonstration of High Rate Algal Ponds for Enhanced Wastewater Treatment and Biofuel Production. J. Appl. Phycol. 2012, 24 (3), 329-337.

(2) Gonçalves, A. L.; Pires, J. C. M.; Simões, M. A Review on the Use of Microalgal Consortia for Wastewater Treatment. Algal Res. 2017, 24, 403-415.

(3) Arbib, Z.; de Godos Crespo, I.; Corona, E. L.; Rogalla, F. Understanding the Biological Activity of High Rate Algae Ponds through the Calculation of Oxygen Balances. Appl. Microbiol. Biotechnol. 2017, 101 (12), 5189-5198.

(4) Rossi, S.; Bellucci, M.; Marazzi, F.; Mezzanotte, V.; Ficara, E. Activity Assessment of Microalgal-Bacterial Consortia Based on Respirometric Tests. Water Sci. Technol. 2018, 78 (1), 207-215.

(5) Flores-Salgado, G.; Thalasso, F.; Buitrón, G.; Vital-Jácome, M.; Quijano, G. Kinetic Characterization of Microalgal-Bacterial Systems: Contributions of Microalgae and Heterotrophic Bacteria to the Oxygen Balance in Wastewater Treatment. Biochem. Eng. J. 2021, 165, 107819.

(6) Mantovani, M.; Marazzi, F.; Fornaroli, R.; Bellucci, M.; Ficara, E.; Mezzanotte, V. Outdoor Pilot-Scale Raceway as a MicroalgaeBacteria Sidestream Treatment in a WWTP. Sci. Total Environ. 2020, 710, 135583.

(7) Karya, N. G. A. I.; van der Steen, N. P.; Lens, P. N. L. PhotoOxygenation to Support Nitrification in an Algal-Bacterial Consortium Treating Artificial Wastewater. Bioresour. Technol. 2013, 134, 244-250.

(8) Rada-Ariza, A. M.; Lopez-Vazquez, C. M.; van der Steen, N. P.; Lens, P. N. L. Nitrification by Microalgal-Bacterial Consortia for Ammonium Removal in Flat Panel Sequencing Batch PhotoBioreactors. Bioresour. Technol. 2017, 245, 81-89. 
(9) Bilanovic, D.; Holland, M.; Starosvetsky, J.; Armon, R. CoCultivation of Microalgae and Nitrifiers for Higher Biomass Production and Better Carbon Capture. Bioresour. Technol. 2016, 220, 282-288.

(10) Torres-Franco, A.; Passos, F.; Figueredo, C.; Mota, C.; Muñoz, R. Current Advances in Microalgae-Based Treatment of HighStrength Wastewaters: Challenges and Opportunities to Enhance Wastewater Treatment Performance. Rev. Environ. Sci. Bio/Technol. 2021, 20, 209.

(11) Rossi, S.; Díez-Montero, R.; Rueda, E.; Castillo Cascino, F.; Parati, K.; García, J.; Ficara, E. Free Ammonia Inhibition in Microalgae and Cyanobacteria Grown in Wastewaters: PhotoRespirometric Evaluation and Modelling. Bioresour. Technol. 2020, 305, 123046.

(12) Delgadillo-Mirquez, L.; Lopes, F.; Taidi, B.; Pareau, D. Nitrogen and Phosphate Removal from Wastewater with a Mixed Microalgae and Bacteria Culture. Biotechnol. Rep. 2016, 11, 18-26.

(13) Van Hulle, S. W. H.; Vandeweyer, H. J. P.; Meesschaert, B. D.; Vanrolleghem, P. A.; Dejans, P.; Dumoulin, A. Engineering Aspects and Practical Application of Autotrophic Nitrogen Removal from Nitrogen Rich Streams. Chem. Eng. J. 2010, 162 (1), 1-20.

(14) Unnithan, V. V.; Unc, A.; Smith, G. B. Mini-Review: A Priori Considerations for Bacteria-Algae Interactions in Algal Biofuel Systems Receiving Municipal Wastewaters. Algal Res. 2014, 4, 35-40.

(15) Sánchez-Zurano, A.; Gómez-Serrano, C.; Acién-Fernández, F. G.; Fernández-Sevilla, J. M.; Molina-Grima, E. A Novel PhotoRespirometry Method to Characterize Consortia in MicroalgaeRelated Wastewater Treatment Processes. Algal Res. 2020, 47, 101858 .

(16) Sutherland, D. L.; Howard-Williams, C.; Turnbull, M. H.; Broady, P. A.; Craggs, R. J. Seasonal Variation in Light Utilisation, Biomass Production and Nutrient Removal by Wastewater Microalgae in a Full-Scale High-Rate Algal Pond. J. Appl. Phycol. 2014, 26 (3), $1317-1329$.

(17) Fagerstone, K. D.; Quinn, J. C.; Bradley, T. H.; De Long, S. K.; Marchese, A. J. Quantitative Measurement of Direct Nitrous Oxide Emissions from Microalgae Cultivation. Environ. Sci. Technol. 2011, 45 (21), 9449-9456.

(18) Plouviez, M.; Chambonnière, P.; Shilton, A.; Packer, M. A.; Guieysse, B. Nitrous Oxide (N2O) Emissions during Real Domestic Wastewater Treatment in an Outdoor Pilot-Scale High Rate Algae Pond. Algal Res. 2019, 44, 101670.

(19) Plouviez, M.; Guieysse, B. Nitrous Oxide Emissions during Microalgae-Based Wastewater Treatment: Current State of the Art and Implication for Greenhouse Gases Budgeting. Water Sci. Technol. 2020, 82 (6), 1025-1030.

(20) Batstone, D. J.; Keller, J.; Angelidaki, I.; Kalyuzhnyi, S. V.; Pavlostathis, S. G.; Rozzi, A.; Sanders, W. T. M.; Siegrist, H.; Vavilin, V. A. The IWA Anaerobic Digestion Model No 1 (ADM1). Water Sci. Technol. 2002, 45 (10), 65-73.

(21) Henze, M.; Gujer, W.; Mino, T.; van Loosedrecht, M. Activated Sludge Models ASM1, ASM2, ASM2d and ASM3. Water Intell. Online 2006, 5 (0), 9781780402369-9781780402369.

(22) Shoener, B. D.; Schramm, S. M.; Béline, F.; Bernard, O.; Martínez, C.; Plósz, B. G.; Snowling, S.; Steyer, J.-P.; Valverde-Pérez, B.; Wágner, D.; Guest, J. S. Microalgae and Cyanobacteria Modeling in Water Resource Recovery Facilities: A Critical Review. Water Res. $X$ 2019, 2, 100024.

(23) Casagli, F.; Zuccaro, G.; Bernard, O.; Steyer, J.-P.; Ficara, E. ALBA: A Comprehensive Growth Model to Optimize Algae-Bacteria Wastewater Treatment in Raceway Ponds. Water Res. 2021, 190, 116734.

(24) Reichert, P.; Borchardt, D.; Henze, M.; Rauch, W.; Shanahan, P.; Somlyódy, L.; Vanrolleghem, P. E. River Water Quality Model No. 1, IWA Sci. Technol. Rep. No. 12; 2002.

(25) Wolf, G.; Picioreanu, C.; van Loosdrecht, M. C. M. Kinetic Modeling of Phototrophic Biofilms: The PHOBIA Model. Biotechnol. Bioeng. 2007, 97 (5), 1064-1079.
(26) Broekhuizen, N.; Park, J. B. K.; McBride, G. B.; Craggs, R. J. Modification, Calibration and Verification of the IWA River Water Quality Model to Simulate a Pilot-Scale High Rate Algal Pond. Water Res. 2012, 46 (9), 2911-2926.

(27) Arashiro, L. T.; Rada-Ariza, A. M.; Wang, M.; van der Steen, P.; Ergas, S. J. Modelling Shortcut Nitrogen Removal from Wastewater Using an Algal-Bacterial Consortium. Water Sci. Technol. 2017, 75 (4), 782-792.

(28) Solimeno, A.; Parker, L.; Lundquist, T.; García, J. Integral Microalgae-Bacteria Model (BIO_ALGAE): Application to Wastewater High Rate Algal Ponds. Sci. Total Environ. 2017, 601-602, 646-657.

(29) Solimeno, A.; Gómez-Serrano, C.; Acién, F. G. BIO ALGAE 2: Improved Model of Microalgae and Bacteria Consortia for Wastewater Treatment. Environ. Sci. Pollut. Res. 2019, 26 (25), 2585525868.

(30) Wágner, D. S.; Valverde-Pérez, B.; Sæbø, M.; Bregua de la Sotilla, M.; Van Wagenen, J.; Smets, B. F.; Plósz, B. Gy. Towards a Consensus-Based Biokinetic Model for Green Microalgae - The ASM-A. Water Res. 2016, 103, 485-499.

(31) Peel, M. C.; Finlayson, B. L.; McMahon, T. A. Updated World Map of the Köppen-Geiger Climate Classification. Hydrol. Earth Syst. Sci. 2007, 11, 1633.

(32) Pizzera, A.; Scaglione, D.; Bellucci, M.; Marazzi, F.; Mezzanotte, V.; Parati, K.; Ficara, E. Digestate Treatment with Algae-Bacteria Consortia: A Field Pilot-Scale Experimentation in a Sub-Optimal Climate Area. Bioresour. Technol. 2019, 274, 232-243.

(33) Bernard, O.; Rémond, B. Validation of a Simple Model Accounting for Light and Temperature Effect on Microalgal Growth. Bioresour. Technol. 2012, 123, 520-527.

(34) Rosso, L.; Lobry, J. R.; Bajard, S.; Flandrois, J. P. Convenient Model To Describe the Combined Effects of Temperature and PH on Microbial Growth. Appl. Environ. Microbiol. 1995, 61 (2), 610-616.

(35) Rosso, L.; Lobry, J. R.; Flandrois, J. P. An Unexpected Correlation between Cardinal Temperatures of Microbial Growth Highlighted by a New Model. J. Theor. Biol. 1993, 162 (4), 447-463.

(36) Béchet, Q.; Shilton, A.; Park, J. B. K.; Craggs, R. J.; Guieysse, B. Universal Temperature Model for Shallow Algal Ponds Provides Improved Accuracy. Environ. Sci. Technol. 2011, 45 (8), 3702-3709.

(37) De Luca, R.; Béchet, Q.; Bezzo, F.; Bernard, O. Optimal Operation of Algal Ponds Accounting for Future Meteorology. IFACPap. 2016, 49 (7), 1062-1067.

(38) Reichert, P. AQUASIM - a Tool for Simulation and Data Analysis of Aquatic Systems. Water Sci. Technol. 1994, 30 (2), 21-30.

(39) de Kreuk, M. K.; Picioreanu, C.; Hosseini, M.; Xavier, J. B.; van Loosdrecht, M. C. M. Kinetic Model of a Granular Sludge SBR: Influences on Nutrient Removal. Biotechnol. Bioeng. 2007, 97 (4), $801-815$.

(40) Demory, D.; Combe, C.; Hartmann, P.; Talec, A.; Pruvost, E.; Hamouda, R.; Souillé, F.; Lamare, P.-O.; Bristeau, M.-O.; SainteMarie, J.; Rabouille, S.; Mairet, F.; Sciandra, A.; Bernard, O. How Do Microalgae Perceive Light in a High-Rate Pond? Towards More Realistic Lagrangian Experiments. R. Soc. Open Sci. 2018, 5 (5), 180523.

(41) Decostere, B.; De Craene, J.; Van Hoey, S.; Vervaeren, H.; Nopens, I.; Van Hulle, S. W. H. Validation of a Microalgal Growth Model Accounting with Inorganic Carbon and Nutrient Kinetics for Wastewater Treatment. Chem. Eng. J. 2016, 285, 189-197.

(42) Béchet, Q.; Sialve, B.; Steyer, J.-P.; Shilton, A.; Guieysse, B. Comparative Assessment of Evaporation Models in Algal Ponds. Algal Res. 2018, 35, 283-291.

(43) Franco-Morgado, M.; Alcántara, C.; Noyola, A.; Muñoz, R.; González-Sánchez, A. A Study of Photosynthetic Biogas Upgrading Based on a High Rate Algal Pond under Alkaline Conditions: Influence of the Illumination Regime. Sci. Total Environ. 2017, 592, 419-425.

(44) Pham, L. A.; Laurent, J.; Bois, P.; Wanko, A. Impacts of Operational Conditions on Oxygen Transfer Rate, Mixing Character- 
istics and Residence Time Distribution in a Pilot Scale High Rate Algal Pond. Water Sci. Technol. 2018, 78 (8), 1782-1791.

(45) Rodero, M. d. R.; Severi, C. A.; Rocher-Rivas, R.; Quijano, G.; Muñoz, R. Long-Term Influence of High Alkalinity on the Performance of Photosynthetic Biogas Upgrading. Fuel 2020, 281, 118804.

(46) Chiaramonti, D.; Prussi, M.; Casini, D.; Tredici, M. R.; Rodolfi, L.; Bassi, N.; Zittelli, G. C.; Bondioli, P. Review of Energy Balance in Raceway Ponds for Microalgae Cultivation: Re-Thinking a Traditional System Is Possible. Appl. Energy 2013, 102, 101-111.

(47) Ginot, V.; Hervé, J.-C. Estimating the Parameters of Dissolved Oxygen Dynamics in Shallow Ponds. Ecol. Modell. 1994, 73 (3), 169187.

(48) Mendoza, J. L.; Granados, M. R.; de Godos, I.; Acién, F. G.; Molina, E.; Heaven, S.; Banks, C. J. Oxygen Transfer and Evolution in Microalgal Culture in Open Raceways. Bioresour. Technol. 2013, 137, $188-195$.

(49) Acién-Fernández, G.; Molina, E.; Reis, A.; Torzillo, G.; Zittelli, G. C.; Sepúlveda, C.; Masojídek, J. 1 - Photobioreactors for the Production of Microalgae. In Microalgae-Based Biofuels and Bioproducts; Gonzalez-Fernandez, C., Muñoz, R., Eds.; Woodhead Publishing Series in Energy; Woodhead Publishing: 2017; pp 1-44, DOI: 10.1016/B978-0-08-101023-5.00001-7.

(50) Dickson, A. G. The Development of the Alkalinity Concept in Marine Chemistry. Mar. Chem. 1992, 40 (1-2), 49-63.

(51) Wolf-Gladrow, D. A.; Zeebe, R. E.; Klaas, C.; Körtzinger, A.; Dickson, A. G. Total Alkalinity: The Explicit Conservative Expression and Its Application to Biogeochemical Processes. Mar. Chem. 2007, 106 (1-2), 287-300.

(52) Audenaert, W. T. M.; Callewaert, M.; Nopens, I.; Cromphout, J.; Vanhoucke, R.; Dumoulin, A.; Dejans, P.; Van Hulle, S. W. H. FullScale Modelling of an Ozone Reactor for Drinking Water Treatment. Chem. Eng. J. 2010, 157 (2-3), 551-557.

(53) Behrenfeld, M.; Marañón, E.; Siegel, D.; Hooker, S. Photoacclimation and Nutrient-Based Model of Light-Saturated Photosynthesis for Quantifying Oceanic Primary Production. Mar. Ecol.: Prog. Ser. 2002, 228, 103-117.

(54) Hauduc, H.; Neumann, M. B.; Muschalla, D.; Gamerith, V.; Gillot, S.; Vanrolleghem, P. A. Efficiency Criteria for Environmental Model Quality Assessment: A Review and Its Application to Wastewater Treatment. Environ. Model. Softw. 2015, 68, 196-204.

(55) Díez-Montero, R.; Belohlav, V.; Ortiz, A.; Uggetti, E.; GarcíaGalán, M. J.; García, J. Evaluation of Daily and Seasonal Variations in a Semi-Closed Photobioreactor for Microalgae-Based Bioremediation of Agricultural Runoff at Full-Scale. Algal Res. 2020, 47, 101859.

(56) Monlau, F.; Sambusiti, C.; Ficara, E.; Aboulkas, A.; Barakat, A.; Carrère, H. New Opportunities for Agricultural Digestate Valorization: Current Situation and Perspectives. Energy Environ. Sci. 2015, 8 (9), 2600-2621.

(57) Akhiar, A.; Battimelli, A.; Torrijos, M.; Carrere, H. Comprehensive Characterization of the Liquid Fraction of Digestates from Full-Scale Anaerobic Co-Digestion. Waste Manage. 2017, 59, $118-128$.

(58) Hélias, A. At the Boundary between Anthropogenic and Environmental Systems: The Neglected Emissions of Indirect Nitrous Oxide. Int. J. Life Cycle Assess. 2019, 24 (3), 412-418.

(59) Sutherland, D. L.; Howard-Williams, C.; Turnbull, M. H.; Broady, P. A.; Craggs, R. J. The Effects of $\mathrm{CO} 2$ Addition along a $\mathrm{PH}$ Gradient on Wastewater Microalgal Photo-Physiology, Biomass Production and Nutrient Removal. Water Res. 2015, 70, 9-26.

(60) Galès, A.; Triplet, S.; Geoffroy, T.; Roques, C.; Carré, C.; Le Floc'h, E.; Lanfranchi, M.; Simier, M.; Roque d'Orbcastel, E.; Przybyla, C.; Fouilland, E. Control of the $\mathrm{PH}$ for Marine Microalgae Polycultures: A Key Point for $\mathrm{CO} 2$ Fixation Improvement in Intensive Cultures. J. CO2 Util. 2020, 38, 187-193.

(61) de Godos, I.; Arbib, Z.; Lara, E.; Rogalla, F. Evaluation of High Rate Algae Ponds for Treatment of Anaerobically Digested Wastewater: Effect of $\mathrm{CO} 2$ Addition and Modification of Dilution Rate. Bioresour. Technol. 2016, 220, 253-261.
(62) Liu, Y.; Zhou, H.; Wang, J.; Liu, X.; Cheng, K.; Li, L.; Zheng, J.; Zhang, X.; Zheng, J.; Pan, G. Short-Term Response of Nitrifier Communities and Potential Nitrification Activity to Elevated $\mathrm{CO} 2$ and Temperature Interaction in a Chinese Paddy Field. Appl. Soil Ecol. 2015, 96, 88-98.

(63) Ganigué, R.; López, H.; Balaguer, M. D.; Colprim, J. Partial Ammonium Oxidation to Nitrite of High Ammonium Content Urban Landfill Leachates. Water Res. 2007, 41 (15), 3317-3326.

(64) Rossi, S.; Casagli, F.; Mantovani, M.; Mezzanotte, V.; Ficara, E. Selection of Photosynthesis and Respiration Models to Assess the Effect of Environmental Conditions on Mixed Microalgae Consortia Grown on Wastewater. Bioresour. Technol. 2020, 305, 122995.

(65) Sánchez-Zurano, A.; Serrano, C. G.; Acién-Fernández, F. G.; Fernández-Sevilla, J. M.; Molina-Grima, E. Modeling of Photosynthesis and Respiration Rate for Microalgae-Bacteria Consortia. Biotechnol. Bioeng. 2021, 118, 952.

(66) Jiang, D.; Khunjar, W. O.; Wett, B.; Murthy, S. N.; Chandran, K. Characterizing the Metabolic Trade-off in Nitrosomonas Europaea in Response to Changes in Inorganic Carbon Supply. Environ. Sci. Technol. 2015, 49 (4), 2523-2531.

(67) Mellbye, B. L.; Giguere, A.; Chaplen, F.; Bottomley, P. J.; Sayavedra-Soto, L. A. Steady-State Growth under Inorganic Carbon Limitation Conditions Increases Energy Consumption for Maintenance and Enhances Nitrous Oxide Production in Nitrosomonas Europaea. Appl. Environ. Microbiol. 2016, 82 (11), 3310-3318.

(68) Ni, B.-J.; Yuan, Z.; Chandran, K.; Vanrolleghem, P. A.; Murthy, S. Evaluating Four Mathematical Models for Nitrous Oxide Production by Autotrophic Ammonia-Oxidizing Bacteria. Biotechnol. Bioeng. 2013, 110 (1), 153-163.

(69) Spérandio, M.; Pocquet, M.; Guo, L.; Ni, B.-J.; Vanrolleghem, P.; Yuan, Z. Evaluation of Different Nitrous Oxide Production Models with Four Continuous Long-Term Wastewater Treatment Process Data Series. Bioprocess Biosyst. Eng. 2016, 39, 493.

(70) Peng, L.; Ni, B.-J.; Law, Y.; Yuan, Z. Modeling N2O Production by Ammonia Oxidizing Bacteria at Varying Inorganic Carbon Concentrations by Coupling the Catabolic and Anabolic Processes. Chem. Eng. Sci. 2016, 144, 386-394.

(71) Lardon, L.; Hélias, A.; Sialve, B.; Steyer, J.-P.; Bernard, O. LifeCycle Assessment of Biodiesel Production from Microalgae. Environ. Sci. Technol. 2009, 43 (17), 6475-6481.

(72) Morales, M.; Collet, P.; Lardon, L.; Hélias, A.; Steyer, J.-P.; Bernard, O. Chapter 20 - Life-Cycle Assessment of Microalgal-Based Biofuel. In Biofuels from Algae, 2nd ed.; Pandey, A., Chang, J.-S., Soccol, C. R., Lee, D.-J., Chisti, Y., Eds.; Biomass, Biofuels, Biochemicals; Elsevier: 2019; pp 507-550, DOI: 10.1016/B978-0444-64192-2.00020-2.

(73) Lin, Y.; Guo, M.; Shah, N.; Stuckey, D. C. Economic and Environmental Evaluation of Nitrogen Removal and Recovery Methods from Wastewater. Bioresour. Technol. 2016, 215, 227-238. 